De Medio Aevo

ISSN-e 2255-5889

\title{
En las fauces de Leviatán: contextos iconográficos de la boca zoomorfa del infierno en el imaginario medieval ${ }^{1}$
}

\author{
José Julio García Arranz²
}

Recibido: 09/01/ 2019/ Aceptado: 24/05/2019 / Publicado: 01/07/2019

Resumen. En numerosas representaciones artísticas de temas como el Infierno, el Juicio final, la Anastasis o la Caída de los Ángeles Rebeldes, o en la ilustración de determinados pasajes procedentes del Apocalipsis, podemos observar la frecuente inclusión de un terrible motivo icónico: unas enormes fauces abiertas de rasgos zoomórficos, a menudo llameantes, caracterización alegorizada de la boca o entrada del infierno al que van a parar los condenados, que en algunas ocasiones nos permite entrever las terribles torturas que tienen lugar en su interior, y que en otras se transforma en umbral de tránsito por el que diversas criaturas infernales emergen del inframundo y acceden al mundo terrenal. El objetivo del presente trabajo es establecer la conexión de esta figura infernal con el relato mítico de Leviatán, gigantesca criatura acuática de muy remotos orígenes, al tiempo que analizar sus precedentes literarios y artísticos, y las más importantes manifestaciones gráficas y variantes del tipo iconográfico de las fauces infernales en el imaginario medieval occidental.

Palabras clave: Leviatán, Boca del Infierno, Apocalipsis, Juicio final, Anastasis.

\section{[en] In the jaws of Leviathan: iconographic contexts of the zoomorphic mouth of hell in the medieval imaginary}

\begin{abstract}
In numerous artistic depictions of themes such as Hell, the Last Judgment, the Resurrection or the Fall of the Rebel Angels, or in the illustration of certain passages from the Apocalypse, we can see the frequent inclusion of a terrible iconic motif: enormous open jaws with zoomorphic features, often ablaze, an allegorized characterization of the mouth or entrance of hell to which the condemned go, and which sometimes allow us to glimpse the terrible tortures that take place inside, or which on other occasions are transformed into the threshold of a passage through which various infernal creatures emerge from the underworld and access the earthly realm. The aim of this work is to establish the connection between this infernal figure and the legendary story of the Leviathan, a gigantic aquatic creature with very ancient origins, while analysing its literary and artistic precedents, and the most important graphic manifestations and variants of the iconographic type of infernal jaws in the western medieval imaginary.
\end{abstract}

Keywords: Leviathan, Mouth of Hell, Apocalypse, Final Judgment, Resurrection.

1 El presente trabajo se ha realizado en el marco del proyecto "Los tipos iconográficos de la tradición cristiana: Antiguo Testamento I" (HAR 2015-65176), dirigido por el profesor Rafael García Mahíques, de la Universitat de València, y financiado por el Ministerio de Ciencia e Innovación. De igual modo, su elaboración se ha llevado a cabo dentro de una Ayuda PRI de la Junta de Extremadura y fondos FEDER "Una manera de hacer Europa", GR 15097 (Decreto 279/2014), a través del Grupo de Investigación

"Patrimonio\&ARTE. Unidad de Conservación del Patrimonio Artístico", dirigido por la Dra. Pilar Mogollón Cano-Cortés.

$2 \quad$ Universidad de Extremadura. e-mail: jjturko@gmail.com. ORCID: 0000-0002-7052-8754 
Sumario. 1. El mito de Leviatán y su vinculación a la iconografía demoníaca e infernal en el cristianismo medieval. 2. La configuración del tipo iconográfico de la boca zoomorfa del infierno. 3 . Variantes del tipo de la boca zoomorfa del infierno en la iconografía medieval europea. 3.1. Las fauces de Leviatán como acceso al infierno, o lugar de tránsito de criaturas demoníacas. 3.2. Leviatán como boca monstruosa de entrada al infierno situada en un paraje infernal o en representaciones apocalípticas y del Juicio final. 3.3. Leviatán como boca monstruosa de entrada al infierno en la Anastasis o Descenso al Limbo. 3.4. Leviatán como boca monstruosa de entrada al infierno de la que surge la Muerte como jinete del Apocalipsis. 3.5. El infierno en el que caen los ángeles rebeldes representado como la boca de Leviatán. 3.6. Leviatán como boca monstruosa de entrada al infierno situada el centro de un esquema cosmográfico. 4. Conclusiones. 5. Referencias bibliográficas.

Cómo citar: García Arranz, J. J. (2019), "En las fauces de Leviatán: contextos iconográficos de la boca zoomorfa del infierno en el imaginario medieval", De Medio Aevo 13, 37-81.

\section{El mito de Leviatán y su vinculación a la iconografía demoníaca e infernal en el cristianismo medieval}

En un sugerente pasaje descriptivo que se incluye al final del Libro de Job, Yahveh invita al protagonista de este relato bíblico a contemplar y admirar a dos formidables criaturas míticas procedentes de la era del caos primigenio ${ }^{3}$, prodigios que el Señor le muestra orgulloso como encarnación de las tremendas fuerzas hostiles de la creación sobre las que ejerce su dominio. Una de ellas es Behemot [la "Bestia" o el "Bruto"] ${ }^{4}$ ( Jb 40,15-24 -10-19 en la Vulgata-), posible descripción de un hipopóta$\mathrm{mo}^{5}$, especie frecuente en el río Nilo -aunque no en el Jordán-, y que en la posterior literatura patrística se verá asociado a motivos zoomorfos de orientación maléfica como son el cocodrilo y la serpiente, de donde procede su relación con la figura del Diablo; el otro ser prodigioso es Leviatán, entidad que aparece caracterizada del siguiente modo:

¿Quién abrió las hojas de sus fauces?

¡Reina el terror entre sus dientes! Su dorso son hileras de escudos, que cierra un sello de piedra.

[...]

Echa luz su estornudo,

sus ojos son como los párpados de la aurora. Salen antorchas de sus fauces, chispas de fuego saltan. De sus narices sale humo,

como de un caldero que hierve junto al fuego. Su soplo enciende carbones, una llama sale de su boca.

En su cuello se asienta la fuerza, y ante él cunde el espanto.

Cuando se yergue, se amedrentan las olas, y las ondas del mar se retiran.

3 No faltan testimonios que equiparan a Behemot con el pez Bahmut, una especie de ballena de la cosmografía islámica que nada en un océano cósmico soportado por las alas de un ángel o jinn, y sobre la que se dispone un gigantesco toro o buey (ar-Rayyan) encima de cuyo lomo descansa a su vez el globo de la tierra. Vid. Chevalier, Jean y Gheerbrant, Alain (1988), Diccionario de simbolos, Herder, Barcelona, 172, s. v. "Ballena".

4 Para algunos investigadores, en efecto, Behemot puede ser el plural intensivo de la voz hebrea " $b$ 'hemah", que significa "bestia".

5 Según Richard Barber y Anne Riches -(1975) A Dictionary of Fabulous Beasts, Ipswich, The Boydell Press, 24-25-, este símbolo podría derivar de la diosa-hipopótamo egipcia Taueret o Tueris. 

$[\ldots]$
Como una olla hace brotar el abismo, Cambia el mar en pebetero.
Deja tras sí una estela luminosa,
el abismo diríase una melena blanca".

En estos versos tan formidable criatura, como fuerza colosal que vive en el medio marino ${ }^{7}$, no sólo se asimila a las nociones de peligro, miedo y muerte asociadas habitualmente al océano, que suscitan en el hombre sentimientos de fragilidad e inseguridad: se concibe al mismo tiempo como un poderoso enemigo que obstaculiza el diálogo con Dios, en una acción similar a la que se atribuye al Diablo a lo largo del Antiguo Testamento en su tradicional papel como rival u oponente a la voluntad del Creador. De este modo, el Leviatán del Libro de Job, o el que se menciona en Is 27,1 -“Aquel día castigará Yahveh con su espada dura, grande, fuerte, a Leviatán, serpiente huidiza, a Leviatán, serpiente tortuosa, y matará al dragón que hay en el mar"-, se llegarán a identificar con las bestias apocalípticas, y en especial con el Dragón rojo

que persigue a la "Mujer vestida de sol" y lucha con Miguel y sus ángeles en $\mathrm{Ap}$ 12. Tal vinculación explica su asociación a la personalidad de Satanás, y más específicamente, a la vista de la descripción que hemos reproducido más arriba, a la figura de la gran boca abierta como entrada del infierno, y justifica, como comprobaremos en las siguientes páginas, su iconografía más habitual en el arte cristiano medieval. Es por ello que Leviatán se suma al extenso listado de nombres con que se designa al Diablo cristiano, o a una de sus más notables encarnaciones, aunque sin renunciar por completo al recuerdo del monstruo marino mitológico.

Fue san Jerónimo quien, en sus comentarios del Libro de Job (Commentarii in Librum Job $)^{8}$, consideraba que tanto Leviatán como Behemot son figuraciones simbólicas del "enemigo", esto es, del propio Satanás. Por su parte, Isidoro de Sevilla, quien enumera los distintos nombres para el Diablo derivados de fuentes grecorromanas o hebreas -Febo, Diana, Saturno, Bel, Belfegor, Beelzebub y Belial-, incluye en su relación las denominaciones de Behemot y Leviatán. El arzobispo hispalense escribe sobre este último:

Se le llama también Leviatán, es decir, 'serpiente de agua', porque con ligera astucia se mueve en el mar de este mundo. Leviatán se interpreta como 'lo que está vinculado a ellos' ¿A quiénes, sino a los hombres, cuyo delito de prevaricación provocó una vez en el paraíso, y diariamente, hasta la muerte eterna, intenta que vuelva a cometerse y se extienda??.

De igual modo Gregorio Magno, inspirándose en la tradición patrística, recurrirá a las descripciones de Behemot y Leviatán para completar su imagen literaria del Maligno $^{10}$, textos que obtendrán una notoria repercusión posterior.

\footnotetext{
6 Jb 41,6-24 -4-23 en la Vulgata-. El texto procede de la Biblia de Jerusalén. La criatura, mencionada también en $J b 3,8$ se identifica con la Serpiente Huidiza del caos primitivo de $J b 26,13$.

Vid. Sal 104,26.

$8 \quad$ En Migne, Jean- Paul, PL, XXVI, cols. 824-844.

9 Orig. 8,11,27-28. El texto procede de Isidoro de Sevilla (1982), Etimologías, texto latino, versión española y notas de J. Oroz Reta, J. y M. A. Marcos Casquero, Madrid, BAC, vol. I, 723.

10 GREG., Mor. 4,9; 32,23; 34,6.
} 
En cuanto a los orígenes míticos de la criatura que subyace bajo el término "Leviatán", se ha establecido una conexión entre éste y el nombre canaanita Lotán, relacionado a su vez con Tiamat, entidad que en la épica babilónica personificaba a las aguas saladas primordiales y del caos primitivo, vencida por el dios organizador del mundo, y con la Hidra griega, dragón de siete cabezas que infestaba el océano. También en las leyendas fenicias encontramos a un monstruo primigenio que habitaba en el mar, identificado con la misteriosa bestia que podía engullir momentáneamente al sol como explicación mitológica del fenómeno del eclipse, y que resultó derrotado, según se decía, por el dios Baal. Norman Cohn ${ }^{11}$ nos habla de un mito sumerio acerca de un combate entre una deidad y el monstruo del caos. Según este relato, el mundo ordenado se vería amenazado por criaturas prodigiosas que surgían del $a b z u$-las entrañas de la tierra-, y que contaban con todo el poder destructivo de aquellas aguas caóticas. Uno de estos seres, Labbu, era un gigantesco dragón marino de $400 \mathrm{~km}$ de longitud y $45 \mathrm{~km}$ de altura, que ocasionalmente se acercaba a la orilla para arrasar la tierra, matar a personas y animales, y aterrorizar incluso a los dioses. Fue el señor de la tormenta el que finalmente cabalgó sobre las nubes y logró aniquilar al dragón, hazaña que, según parece, le granjeó el reinado sobre las restantes divinidades. De igual modo ${ }^{12}$, Baal estableció en un principio su dominio sobre el mundo subyugando las rebeldes aguas cósmicas, simbolizadas por una serpiente o un dragón; posiblemente este relato inspire las referencias de los salmos ( Sal 29,3; 74,13-14; 89,9-10; $93,4)$ y de otros textos bíblicos ( $\mathrm{Ha} \mathrm{3,8;} \mathrm{Jb} 7,12 ; 26,12-13$; Is 51,10), en los que se describe a Yahveh derrotando a las aguas junto con los dragones Leviatán y Ráhab ${ }^{13}$, y proclamando de ese modo su hegemonía en una concepción de la creación, de acuerdo con los vestigios de aquellas tradiciones orientales, como victoria de Dios sobre sus más formidables oponentes. En ciertos pasajes de mitos ugaríticos, en fin, el dios del mar se identifica con una serpiente o con un dragón ${ }^{14}$. De este modo, en un par de ocasiones la hermana de Baal, Anat, recuerda a éste cómo ella le ayudó en el decisivo combate para someter al monstruo del caos, denominado unas veces Yam y otras Leviatán:
¿Acaso no destruí a Yam, amado de El
$[\ldots]$
¿Acaso no fue capturado (y) derrotado el dragón? Destruí la serpiente escurridiza, Al tirano de siete cabezas.
[...] tú heriste a Leviatán la serpiente escurridiza,
Tú acabaste con la serpiente escurridiza, El tirano de siete cabezas ${ }^{15}$.

Desde un punto de vista etimológico, “Leviatán” procede del término hebreo liwyathan, que significa "retorcido" o "enroscado", y de ahí "serpiente monstruosa", y es prodigio muy frecuente en la mitología semítica, así como en la literatura rabí-

\footnotetext{
11 Cohn, Norman (1995), El cosmos, el caos y el mundo venidero. Las antiguas raíces de la fe apocaliptica, Barcelona, Crítica, 58-59.

12 Cohn, Norman, op. cit., 148-149.

13 Este último monstruo aparece citado expresamente en Is 51,9; Jb 9,13; 26,12-13; y Sal 89,11.

14 Cohn, Norman, op. cit., 140-141.

15 La versión inglesa de estos textos procede de Gibson, John C. L. (1978), Canaanite Myths and Legends, Edimburgo, T. \& T. Clarke, 50 y 68. La traducción es nuestra.
} 
nica y apocalíptica. Robert Graves y Raphael Patai trazaron de manera detallada el perfil mítico de la criatura a través de diversas notas procedentes de aquella tradición hebrea, que reúnen y sintetizan en su conocido libro ${ }^{16}$. De este modo, cuando Dios creó los peces y las bestias marinas con luz y agua, permitió a Leviatán, que era más grande que todos sus congéneres juntos, gobernarlos desde una suerte de trono erigido sobre una roca colosal bajo la superficie del mar. Los grandes dragones marinos le sirven de alimento; bebe el agua de un afluente del Jordán mientras desemboca en el océano por un canal secreto. Según algunos autores se trataba de un monstruo con múltiples cabezas, o bien que existían dos "Leviatanes" -la serpiente huidiza y la serpiente tortuosa-. Se considera que tiene tantos ojos como días el año, y escamas radiantes que oscurecen al propio sol. Acostumbra a morder su cola entre los dientes formando un anillo alrededor del Océano; la franja inferior del firmamento, donde se contienen los signos del Zodíaco, recibe por ello el nombre de "Leviatán". De acuerdo con una de las vertientes de la leyenda, Dios acabó destruyéndolo: pescó éste a la gran bestia con un anzuelo, la sacó del Abismo, sujetó su lengua con un cordel, le atravesó la nariz con un junco y taladró su quijada con un gancho, de manera similar a como se hace con los peces de río. Después arrojó su cadáver al fondo de una barca y se lo llevó como si fuera a vender su mercancía al mercado (Is 27,1; Sal 74,14; Jb 40,25-32;41,2-26).

Otros relatos, en cambio, afirman que Dios perdonó a Leviatán por ser una de sus criaturas, pero lo domesticó por completo, o bien que ordenó al arcángel Jahoel -o Gabriel- que hiciera tal cosa. Los textos rabínicos recogen en este sentido una leyenda según la cual Leviatán fue creado, junto con Behemot, el quinto día del Génesis, y luego fue sometido definitivamente por Gabriel con ayuda de Yahveh. De este modo, en el texto de una maldición cabalística, podemos leer: "Dios juega con él (Leviatán) durante el último cuarto de cada día, y el río Jordán desemboca en sus fauces. En el día del Juicio su carne servirá de alimento para los justos y parte de su piel será para ellos como una tienda. El resto cubrirá los muros de Jerusalén, desde donde su fulgor podrá verse hasta los confines de la tierra" ${ }^{17}$. A la espera de tan terrible destino final, el monstruo fue encerrado por Dios en una gran cueva del océano donde todo el peso del mundo descansa sobre él.

Añaden Graves y Patai que algunos sabios concilian las tradiciones opuestas que hablan sobre la muerte o esclavitud de Leviatán mediante la creencia de que el Señor creó un macho y una hembra para así poder justificar ambos destinos. De este modo, en un pasaje del Libro de Enoc (60,7-9), se nos presenta a ambos seres primigenios, Leviatán y Behemot, como una pareja de monstruos de distinto sexo que fueron separados de modo que el primero de ellos "mora en los abismos del océano sobre las fuentes de las aguas", en tanto el otro fue arrojado a "la tierra firme del desierto" que se abre al oriente del Jardín del Edén ${ }^{18}$. De acuerdo con estas referencias, Dios mató a la hembra y castró al macho para impedir que se aparearan y de ese modo destruyeran el mundo. Otros anuncian un futuro duelo a muerte entre Leviatán y Behemot. Tras un combate estremecedor en la orilla del mar, los cuernos curvos de Behemot desga-

16 (2009), Los mitos hebreos, Madrid, Alianza, 54-55.

17 La referencia procede de Barber, Richard y Riches, Anne, op. cit., 97; hemos tomado la traducción de Chevalier, Jean y Gheerbrant, Alain, op. cit., 643, s. v. "Leviatán".

18 El texto procede de Libro de Enoc el Profeta (El) (2005), traducción española de Fermín Navascués a partir de la versión inglesa del texto etíope realizada por R. H. Charles, Madrid, Edaf, 76. 
rrarán a Leviatán mientras las afiladas aletas de éste hieren mortalmente al monstruo terrestre. Otros sostienen, en fin, que Leviatán debería haber sido el compañero de Behemot, pero que Dios los separó, dejando a éste en tierra seca y enviando a Leviatán al mar, para que su peso conjunto no resquebrajara la bóveda del mundo [Fig. 1].

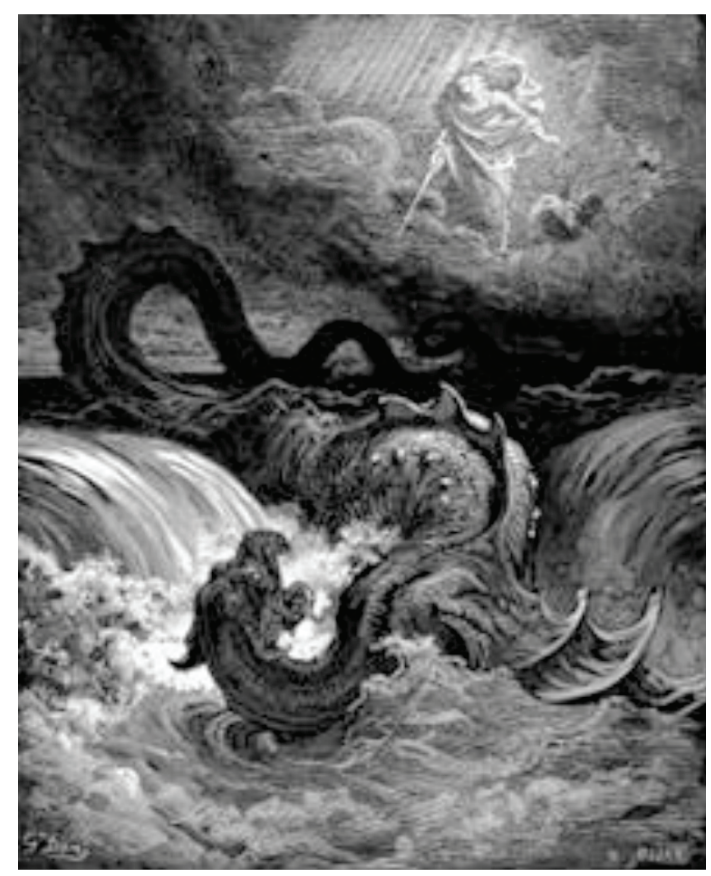

Fig. 1. La destrucción de Leviatán, ilustración grabada a partir de un diseño de Gustave Doré para La Biblia (1865).

Buena parte de estos relatos míticos aparecerán reflejados en el Antiguo Testamento, en especial en aquellos episodios donde Yahveh adopta el papel del primitivo Baal ( Jb 7,12; 9,13; Sal $74-73$ en la Vulgata-,13-14) ${ }^{19}$. Para Isaías, de acuerdo con el ya reproducido pasaje de $27,1^{20}$, la destrucción de Leviatán simbolizaba la muerte final de los no redimidos, entre quienes no se encontraba el pueblo de Israel. Se ha tratado de identificar, además de con la serpiente, con un "gran pez" o ballena, o un cocodrilo $^{21}$, ideas reduccionistas ante el aspecto evidentemente mítico y simbólico

19 “[...] tú hendiste el mar con tu poder, / quebraste las cabezas de los monstruos en las aguas; / tú machacaste las cabezas de Leviatán / y las hiciste pasto de las fieras”. El texto procede de la Biblia de Jerusalén.

20 Con este u otros pasajes similares - Is 51,9: “¿Despierta, despierta, revístete de poderío, / oh brazo de Yahveh! / [...] ¿No eres tú el que partió a Ráhab, / el que atravesó al Dragón?”; texto procedente de la Biblia de Jerusalén-, en los que se describe una imagen primigenia de Dios sometiendo el mar a su dominio, aplastando el dragón del caos y venciendo a los poderes de las tinieblas como expresión de su victoria sobre toda la creación, se quiere transmitir a los creyentes la esperanza de que en el futuro los enemigos del Señor serán aniquilados. Vid. al respecto Lurker, Manfred (1994), Diccionario de imágenes y símbolos de la Biblia, Madrid, El Almendro, 90-91, s. v. "Dragón".

21 Esta propuesta se basa esencialmente en los pasajes de Ezequiel en los que éste compara al faraón de Egipto con un cocodrilo. Así en Ez 29,3-4: “Aquí estoy contra ti, Faraón, rey de Egipto, gran cocodrilo, recostado en medio de sus Nilos, tú que has dicho: 'Mi Nilo es mío, yo mismo lo he hecho'. Voy a ponerte garfios en las quijadas, pegaré 
de este ser, una especie de dragón acuático que de algún modo actúa como emblema o epítome de todos los animales marinos, como Behemot lo era de los terrestres. Según $\mathrm{Sal} 74,14$, Leviatán tiene varias cabezas, lo que implicaría la idea de que se trata de un dragón pluricéfalo, detalle que parece proceder de la mitología semítica: en un texto de Ugarit se describe como un monstruo de siete cabezas ${ }^{22}$. De todos estos textos bíblicos se obtiene la impresión general de que se trata de un ser que reposa adormecido en el mar, cuyo despertar, temido siempre por la imaginación popular, se puede producir si se excita a la bestia, o se la atrae por medio de una maldición eficaz contra el orden existente.

Ya indicamos más arriba que fue san Jerónimo quien identificó a las bestias del Libro de Job con el Diablo ${ }^{23}$, entendiendo que Leviatán no es otra cosa que un nuevo término para designar a una entidad diabólica -aspecto fácilmente deducible a partir del detalle de las llamas que surgen de la nariz y boca del monstruo de acuerdo con la descripción bíblica-, y que, a diferencia de Behemot, entidad terrestre, es una criatura acuática que habita en las aguas del mar (magnus draco). De este modo, fundamentándose en los versículos de $I s 27,1$ y Sal 74,13-14, señala aquél que, de acuerdo con algunos autores, la potencia y astucia atribuidas a Satanás han tomado cuerpo en el horrible dragón marino. Otra sugerencia de Jerónimo, que encontrará eco en la literatura apocalíptica de los siglos XIV-XVII, es su conexión con el dragón del Apocalipsis, al que define como caput et princeps omnium superborum ${ }^{24}$ [Fig. 2].

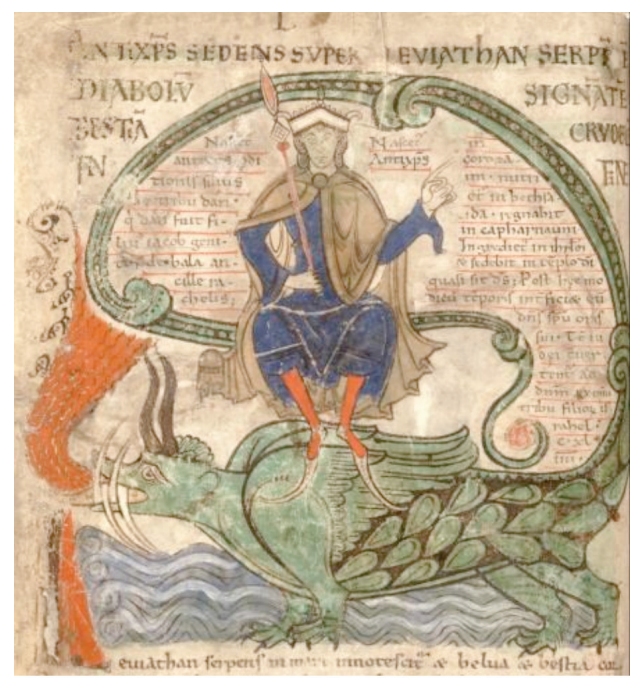

Fig. 2. El Anticristo sedente sobre Leviatán, Liber floridus de Lambert de Saint Omer, manuscrito, s. XII. Gante, Bibliothèque de l'Université, ms 92, f. 62v.

a tus escamas los peces de tus Nilos, te sacaré fuera de tus Nilos, con todos los peces de tus Nilos pegados a tus escamas"; o en Ez 32,2-3: "Eras (Faraón) como un cocodrilo en los mares, chapoteabas en tus ríos, enturbiabas el agua con tus patas, agitabas su corriente. Así dice el Señor Yahveh: Yo echaré sobre ti mi red entre una asamblea de pueblos numerosos, en mi red te sacarán". Los textos reproducidos proceden de la Biblia de Jerusalén.

22 Vid. Brandon, Samuel George F. (1975), Diccionario de religiones comparadas, Madrid, Ediciones Cristiandad, vol. II, 928, s. v. "Leviatán".

23 Commentarii in Librum Job; en Migne, Jean-Paul, PL, XXVI, cols. 824-844.

24 Op. cit., col. 844. 
Como síntesis de todo lo anterior, Fray Luis de León escribirá en su Exposición del Libro de Job:

Leviathan [...] llaman los hebreos à los dragones marinos, y señaladamente à las ballenas, que entre todos son de señalada grandeza, quales son las que crían los mares que están más sujetos al norte, de que los Autores escriben cosas muy prodigiosas. Pues de estos animales habla ahora aquí Dios, como de obras suyas maravillosas; porque ansí la desmedida grandeza de sus cuerpos, como las figuras de sus miembros extraordinarias, son cosas de espanto, y que hacen por mil razones argumento claro y certísimo, no solo de que Dios sabe y puede mucho, sino también de lo poco que el hombre vale, pues no allega à poder mirar sin temor, lo que Dios hace como un juego ${ }^{25}$.

Y, en otro lugar:

[Leviathan] es palabra de diversos sentidos [...]. Porque Leviathan según una significación es ò ballena, ò cualquier otro pez de enorme grandeza, que por figura en la Sagrada Escritura à veces significa el demonio [...]. Y aun si Leviathan es el demonio aquí por figura, aun encarece mas Job lo que quiere: porque los dispuestos à levantar el demonio son aquí los hechiceros, y los que entran en cerco, para traherle à su presencia: los quales no solo aborrecen la luz, y la maldicen si viene, ò quando viene à estorvarles su oficio (que es oficio que ama la noche) mas en esa mesma obra de su cerco, y conjuros usan de maldiciones espantosas, y de palabras horribles ${ }^{26}$.

Sin embargo, toda esta tradición literaria acerca de la colosal bestia marina apenas ha tenido repercusión, como veremos, en la iconografía "diabólica" de Leviatán que se desarrolla a partir de la Baja Edad Media. Por el contrario, casi siempre aparece representado como un gran dragón de enorme boca, que hace las funciones de entrada al reino infernal y engulle por ello a los condenados, caracterización que a veces es suplantada por los rasgos de otras bestias "devorantes" como el lobo, el oso, el león o un gran pez. Tal vez a este tipo de representaciones haga referencia el mercedario fray Juan Interián de Ayala en El pintor cristiano y erudito cuando justifica la representación del Maligno por medio de grandes bestias flamígeras más o menos directamente inspiradas en la tradición legendaria de Behemot o Leviatán:

Pintan también muchas veces a los demonios en figuras de terribles fieras que están respirando fuego por los ojos, por la boca y por las narices, sobre lo que tampoco nada hay que reprehender, singularmente si se hace reflexión sobre aquella exactísima descripción que hacen las sagradas Letras (Job, 40,10 et 20; Isai., $27,1)$ del demonio a quien apellidan ya con el nombre de Behemoth, y ya con el de Leviathan. Porque, si bien en esta descripción, conforme han notado gravísimos intérpretes, en el sentido literal se entiende una bestia disforme como es el rinoceronte, o como decimos los españoles la abada; sin embargo observan los mismos que también en un sentido propiísimo se hace una bella y exacta pintura

\footnotetext{
25 40,20. La traducción procede de Luis de León (1985), Exposición del Libro de Job, Madrid, Hyspamérica Ediciones, 689.

26 3,7. La traducción procede de la edición citada, 54-55.
} 
del demonio: pues el que por la boca y por las narices estén respirando humo y fuego, fácilmente da a entender su espantosa ferocidad y una crueldad superior a lo que podrían concebir nuestras fuerzas para causar terror. Por esto la Sagrada Escritura, describiendo a Leviathan [...], y bajo cuya figura está bastante claro que se significa al demonio, nos la pintan con tan varios y elegantes colores en las siguientes palabras (Job 41, 9-12). Esta es sin duda una bellísima hipotiposis, de la que se colige ser muy propio y conforme, no sólo a la elocuencia sagrada, si también muy conducente para la mayor explicación de las mismas cosas, el pintar al demonio respirando y vomitando fuego por la boca, por las narices y por los ojos ${ }^{27}$.

Esta poderosa -y terrorífica- imagen de las fauces infernales se consolida como un arraigado símbolo tradicional que tiene su origen en varias fuentes literarias y plásticas; entre las primeras, además de la citada descripción del Libro de Job, deben mencionarse otras referencias bíblicas en las que se habla explícitamente de las puertas del averno como alusión al poder de Dios sobre la muerte sin retorno ${ }^{28}$, o los pasajes apocalípticos que describen la entrega a un ángel de una llave como instrumento para abrir o cerrar el pozo del abismo en el que permanecen encerrados Satanás y sus acólitos (Ap 9,1-2; 20,1-3), representando así la entrada al foso infernal como una puerta con cerradura. Sin embargo, más allá de esta concepción "arquitectónica" e inanimada de la entrada del Infierno, nada nos dicen los textos bíblicos canónicos que permitan concebirla como las terribles fauces dentadas de una enorme bestia. Tan sólo podemos encontrar una aproximación conceptual en el siguiente pasaje de los Números (16,31-35):

Y sucedió que, nada más terminar de decir estas palabras, se abrió el suelo debajo de ellos; la tierra abrió su boca y se los tragó, con todas sus familias, así como a todos los hombres de Coré, con todos sus bienes. Bajaron vivos al seol con todo lo que tenían. Los cubrió la tierra y desaparecieron de la asamblea [...]. Brotó fuego de Yahveh, que devoró a los doscientos cincuenta hombres que habían ofrecido el incienso ${ }^{29}$.

La inspiración de la concepción de esta boca infernal como una fuerza independiente de Satanás, con voluntad propia, concebida bien como recipiente diseñado por Dios para contener al Diablo ${ }^{30}$, bien como instrumento o refugio de éste, o bien como espantable receptáculo destinado a mantener retenidos a los condenados, debe

27 El pintor cristiano y erudito I,10,2; edición de Barcelona, Imprenta de la Viuda e Hijos de J. Subirana, 1883, $163-164$.

28 Sb 16,13: "Pues tú tienes poder sobre la vida y sobre la muerte, haces bajar a las puertas del Hades y de allí subir"; Si 51,2-6: "Pues protector y auxilio has sido para mí, y has rescatado mi cuerpo de la perdición [...] del ahogo del fuego que me envolvía, de entre el fuego que yo no había encendido, de la hondura de las entrañas del seol"; Is 38,10: "A la mitad de mis días me voy; en las puertas del seol se me asigna un lugar para el resto de mis años" (El "seol" designa en estos pasajes veterotestamentarios las profundidades de la tierra a donde descienden los muertos, buenos o malos, para una lúgubre supervivencia-cfr. por ejemplo $\mathrm{Nm}$ 16,31-33; $\mathrm{Jb} 7,9$; Sal 6,6-, y el término resulta intercambiable con el Hades clásico); $M t$ 16,18: "Y yo a mi vez te digo que tú eres Pedro, y sobre esta piedra edificaré mi Iglesia, y las puertas del Hades no prevalecerán contra ella". Los textos reproducidos proceden de la Biblia de Jerusalén.

29 El texto procede de la Biblia de Jerusalén.

30 En las representaciones de Dios enviando a los ángeles rebeldes a los abismos, condenándolos a penar en la penumbra hasta el día del Juicio final, podemos encontrar también, como ya vimos, ilustraciones de la Boca del Infierno. Este dato no sólo configura a Leviatán como una entidad autónoma y diferente del Diablo, sino, incluso, como una criatura anterior a su caída. 
buscarse más bien en la literatura apócrifa. Ya desde el s. III existen textos en los que se representa al Infierno, igual que a la Muerte, como tales personificaciones autónomas. A aquella centuria pertenece un texto visionario anónimo conocido como Las enseñanzas de Silvano, en el que se describe el descenso de Cristo al mundo subterráneo, quebrando en su camino las barras de bronce y los cerrojos de hierro de la puerta del Infierno; éste, temiendo la escapada de sus cautivos, trató de encadenar al Salvador sin éxito. Cuando Cristo comprendió que tanto la Muerte como el Averno eran aliados del Diablo, decidió romper el "arco del Infierno" para representar así la derrota definitiva de los poderes del Mal. En la segunda parte del Evangelio de Nicodemo (texto compuesto en el s. VI), conocida como Descensus Christi ad Inferos a falta del título original ${ }^{31}$, el Infierno mantiene una discusión con Satanás o Beelzebub sobre las posibilidades que aquél y la Muerte tienen para mantener prisionero a Cristo, y evitar así que les arrebate sus preciadas presas; ante las órdenes de resistir de Satanás, el Infierno trata de reforzar sus colosales puertas, pero Cristo, con una sola palabra, consigue derribarlas y permitir la entrada de la luz en la vieja oscuridad. El Redentor ordena a los ángeles que encadenen a Satán en el fondo del Infierno a la espera de su segunda venida, y el Infierno, aliado hasta entonces del Diablo, se convierte ahora en su guardián ${ }^{32}$. En la versión griega de este texto, al Infierno se le califica de "devorador insaciable de todos" o "tragón insaciable", y se le atribuyen declaraciones como la siguiente: "Hace poco devoré yo a un difunto llamado Lázaro; pero, poco después uno de los vivos con sola su palabra lo arrancó a viva fuerza de mis entrañas [...] porque has de saber que veo agitados a todos los que tengo devorados desde el principio y siento dolores en mi vientre" 33 .

\section{La configuración del tipo iconográfico de la boca zoomorfa del infierno}

Ha sido Luther Link quien más ha profundizado hasta la fecha en los posibles referentes visuales de la imagen de la Boca del Infierno; de acuerdo con este autor ${ }^{34}$, deben tenerse en cuenta las representaciones egipcias de Ammit o Ammyt, el "Devo-

31 De Santos Otero, Aurelio (ed. y trad.) (1988), “Actas de Pilato (o Evangelio de Nicodemo)", Los Evangelios Apócrifos, Madrid, BAC, 390 y ss.

32 Sobre estos textos, vid. Russell, Jeffrey Burton (1994), El Príncipe de las Tinieblas. El poder del mal y del bien en la historia, Santiago de Chile, Andrés Bello, 103-104. Un diálogo semejante entre el Tártaro y el Diablo se recoge en algunos fragmentos conservados del Evangelio de Bartolomé. Por su parte, Luther Link - (2002) El diablo. Una máscara sin rostro, Madrid, Síntesis, 89-90- señala que este tema inspirado en el texto de Nicodemo, conocido como "Angustia del Infierno", mantuvo su popularidad y sentido melodramático a lo largo de la Edad Media gracias a su empleo en diversos autos sacramentales. De acuerdo con estas obras teatrales, ante la inminente llegada de Jesús tras su muerte en la cruz, Satanás, príncipe del Infierno, fue arrojado fuera del éste para que luchara contra aquél. Como era previsible, Satanás fracasa en su misión, y el Salvador logra derribar las verjas del Infierno y abrir sus puertas en forma de colmillos, pasar por encima de la Muerte, encadenar a Satanás, someter el reino del Infierno y liberar a sus cautivos. A causa de semejante catástrofe, el Infierno reprende a Satanás por haber propiciado la muerte de Jesús; como castigo, Satanás es condenado a vivir en el Infierno por toda la eternidad, reemplazando el lugar que antes ocupaban Adán y sus descendientes, como si el Maligno relevara a Adán en su pena y redimiera a los hombres de su castigo. Al final de estas representaciones, Satanás aparece encadenado, y se limita a aullar y jadear como un perro atado. Respecto a la presencia de ingenios con forma de fauces infernales en los misterios o autos medievales, vid. Lima, Robert (1996), "The Mouth of Hell: the Iconography of Damnation On the Stage of the Middle Ages, en Szonyi, Gyorgy E. (ed.), European Iconography East and West, Selected Papers of the Szeged International Conference, June 9-12, 1993, Leiden, Brill, 35-48.

33 De Santos Otero, Aurelio, op. cit., 440-443.

34 Op. cit., 88 y ss. 
rador de los Condenados", con sus fauces de cocodrilo ${ }^{35}$, las imágenes y esculturas clásicas de las puertas de Hades, y la boca de Gorgona ${ }^{36}$, que quizá fuera, en su opinión, el motivo más influyente de entre todos ellos [Fig. 3]. Meyer Schapiro ${ }^{37}$, por su parte, especula con la posibilidad de que esta imagen tenga su precedente en el mito nórdico de Fenrir, vencido por Vidar, ser que nació de la unión entre Loki y Angrboda, que se representa como la boca de un lobo monstruoso ${ }^{38}$, y que es usado como símbolo de Cristo en la Cruz de Gosforth (gran crucero monumental en piedra, del s. $\mathrm{X}$, conservado en el cementerio junto a la iglesia de St Mary, en Gosforth, condado de Cumbria, Inglaterra) [Fig. 4] y otras piezas de arte escandinavo. Pamela Sheingorn $^{39}$ ha insistido en la idea de que no debe sorprendernos esta solución plástica a la hora de representar la entrada al averno cuando en la mentalidad común estaba generalizada la suposición de que los cráteres volcánicos de Sicilia o de otras islas conducían directamente al "otro mundo", de acuerdo con ciertas creencias heredadas de la Antigüedad. En el Dialogus miraculorum de Cesáreo de Heisterbach (ca 1180ca. 1240), un novicio se pregunta sobre la posibilidad de que las almas sean enviadas hacia las cumbres del Estrómboli o el Etna para penetrar así en el purgatorio o en el infierno; el monje narrador replica que aquellas cumbres son denominadas la "boca del Infierno", y, puesto que se supone que el Averno está situado en el corazón de la tierra, hasta allí sólo son enviados los réprobos con el fin de que no puedan volver a contemplar nunca la luz del cielo. Por lo demás, los tremendos ruidos que se perciben en el interior de sus cráteres se consideran como eco de los sonidos infernales y de los gritos emitidos a causa de las atroces torturas aplicadas por los demonios ${ }^{40}$.

Los orígenes del motivo de la boca infernal como fauces de una enorme bestia devorante parecen tener su origen en la Inglaterra anglosajona ${ }^{41}$. Meyer Schapiro indica que el ejemplo más antiguo conservado de este motivo es un relieve de marfil, fechado ca. 800 y conservado en el Victoria and Albert Museum de Londres [Fig. 5]; añade que la mayor parte de los ejemplos anteriores al s. XII son de origen inglés ${ }^{42}$.

35 Es una diosa híbrida con cabeza de cocodrilo, mitad delantera de león y mitad trasera de hipopótamo. Según el Libro de los Muertos permanece expectante al pie de la balanza en la que se pesará el corazón de los difuntos, devorando el de los condenados para que perezcan definitivamente y pierdan así su condición inmortal. Vid. Castel Ronda, Elisa (1995), Diccionario de mitología egipcia, Madrid, Aldebarán, 35.

36 Había tres Gorgonas, Esteno, Euríale y Medusa -las dos primeras inmortales, mortal la tercera-, hijas de divinidades marinas, que habitaban en el occidente extremo, no lejos del reino de los muertos. Sus cabezas estaban rodeadas de serpientes, tenían grandes colmillos similares a los de un jabalí, y alas de oro; sus ojos echaban chispas, y su mirada era tan penetrante que, el que la sufría, quedaba convertido en piedra -Grimal, Pierre (1989), Diccionario de mitología griega y romana, Barcelona, Paidós, 217-. Estos seres presentan, por tanto, rasgos que más tarde caracterizarán al Diablo, sirviendo también probablemente como modelo para la Boca del Infierno, una imagen que, a diferencia de las representaciones de Bes, presenta grandes colmillos.

37 (1980) "Cain's Jaw-Bone that Did the First Murder", en Selected Papers, vol. 3: "Late Antique, Early Christian and Mediaeval Art", Londres, Chatto \& Windus, 257-259.

38 En un detalle de su programa escultórico, Vidar aparece combatiendo con la gran boca del monstruo Fenrir, al que sujeta por sus mandíbulas mientras éste trata de atraparlo con su lengua.

39 (1992) “'Who can open the doors of his face?' The Iconography of Hell Mouth”, en C. Davidson y Th. H. Seiler (eds.), The Iconography of Hell, Kalamazoo (Michigan), Medieval Institute Publications, 2-3.

40 Vid. Le Goff, Jacques (1989), El nacimiento del Purgatorio, Madrid, Taurus, 112; Aragonés Estella, Ma Esperanza, La imagen del mal en el románico navarro, Pamplona, Gobierno de Navarra, 129, nota 321. Esta última autora nos recuerda el precedente clásico de la consideración del Etna como morada del dios Vulcano y de su actividad metalúrgica.

41 En las Homilías Vercelli (4:46-8), texto anglosajón anónimo de finales del s. X, Satanás es representado como un dragón que se traga a los condenados.

42 Op. cit., 257-259. 
Posiblemente su generalización sea resultado de la conjunción en este contexto a finales del s. X de las reformas monásticas y de las invasiones danesas en Inglaterra, situación que indujo a la creación de una iconografía del infierno que pudiera ser comprendida intuitivamente tanto por los cristianos como por los paganos. Aunque algunas imágenes tempranas muestran a un dragón o un ser similar a una serpiente caracterizada por sus agudas mandíbulas, las artes plásticas occidentales pronto dieron preferencia a una cabeza carente de cuerpo, independiente, para figurar así la unidireccionalidad del ser representado por medio de esta boca infernal ${ }^{43}$.

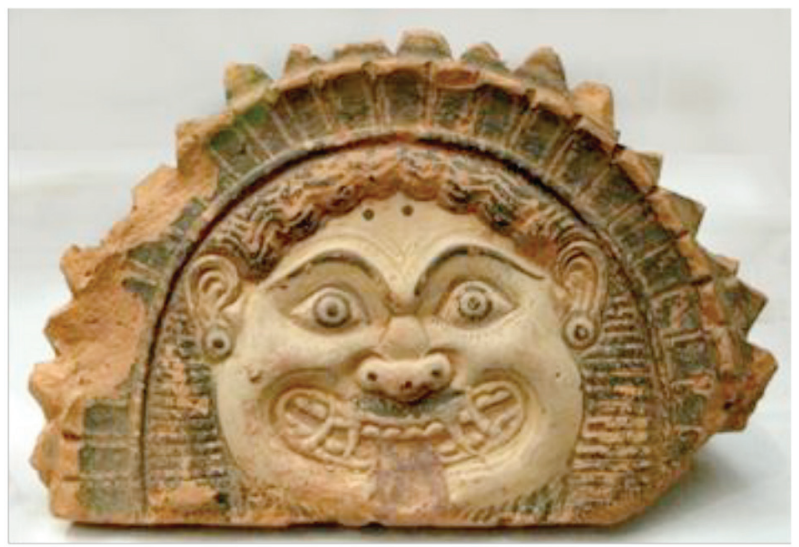

Fig. 3. Antefija griega de terracota con representación de Gorgona, posiblemente procedente de la isla de Fasos, s. IV. a.C. Moscú, Pushkin Museum.

La puerta del Infierno entendida, entonces, como unas enormes fauces abiertas que arrojan llamas como elemento consustancial al demonio y a su mundo infernal, será una fórmula que obtendrá un enorme éxito iconográfico ${ }^{44}$. Pamela Sheingorn ${ }^{45}$ ha trazado una panorámica de los distintos espacios temáticos en los que pueden hacer acto de presencia estas monstruosas fauces devorantes: en lo que se refiere a las ilustraciones del Nuevo Testamento, la Boca del Infierno puede aparecer, aunque muy raramente, en la Tentación de Cristo, o en las parábolas de las Vírgenes prudentes y necias (Mt 25,1-13; Lc 12,35-38) -lintel del tímpano de la portada de la capilla de Santa Ana, del s. XIV, en el castillo de Marienburgo o Malbork (Polonia), plaza fuerte de los caballeros teutónicos-, y la de Lázaro y el hombre rico ( $L c$ 16,19-31). En la vida de los santos, se suele concretar en el castigo que aguarda a aquellos malvados

43 El argumento procede de Galpern, Joyce Ruth M. (1977), The Shape of Hell in Anglo-Saxon England, tesis doctoral inédita (Universidad de California, Berkeley), 142. Hemos tomado la referencia en Sheingorn, Pamela, op. cit., 7.

44 Hemos de indicar aquí que, pese a que la boca monstruosa del Infierno es un motivo iconográfico procedente del Leviatán bíblico, en la literatura tardomedieval y moderna no parece que exista constancia de tal identidad: las fauces del Infierno son una cosa, y Leviatán un ente diferente que puede hacer acto de presencia en las obras de teatro moralizante del momento como un ser diabólico similar a Lucifer y Satanás. De hecho, si seguimos la clasificación demoníaca establecida en la obra del padre Sebastien Michaëlis Histoire admirable de la possession d'une penitente (París, 1612), Leviatán aparece como diablo de la primera jerarquía, antiguo príncipe de los serafines que confunde a los mortales con creencias heréticas, y su santo antagonista es san Pedro.

45 Op. cit., 3-5. 
que persiguen a los hombres justos, o en las escenas en las que la mano de Dios rescata a los patriarcas y profetas que se encontraban cautivos en las infernales fauces.

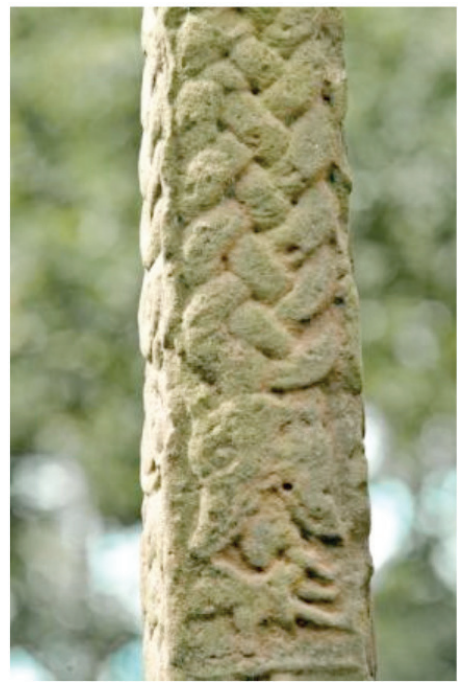

Fig. 4. Gosforth Cross, posible representación de Vidar luchando con el lobo Fenrir en Ragnarök, ca. 900 a.C. Gosforth (Cumbria, Reino Unido), iglesia de St. Mary, detalle del lado oeste.

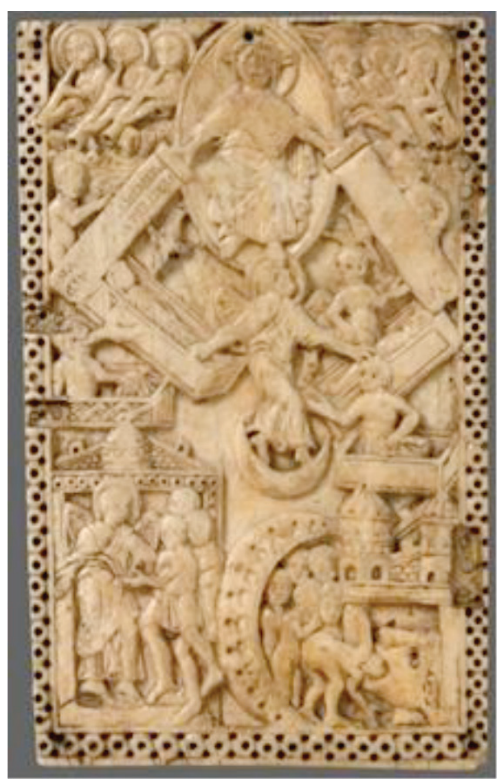

Fig. 5. Juicio final, relieve de marfil, ca. 800. Londres, Victoria and Albert Museum.

Pero, más allá de éstos y otros ejemplos más ocasionales, podemos fijar hasta cuatro variantes fundamentales de este tipo iconográfico, todas ellas inspiradas en 
mayor o menor medida en las ya referidas descripciones apócrifas del infierno: $1^{\circ}$ ) E1 Descenso al Infierno de los Justos, o Limbo -en latín Descensus ad Inferos ${ }^{46} ; 2^{\circ}$ ) Aparición de la Boca del Infierno como elemento escenográfico integrado en amplios parajes infernales o recreaciones del Juicio final; $3^{\circ}$ ) En algunas representaciones del Apocalipsis, podemos encontrar ilustrado el texto referido a la apertura de los cuatro primeros sellos del libro del Cordero - Ap 6,1-7-, imagen que muestra a los cuatro jinetes apocalípticos -bien todos ellos unidos, o bien solamente a la Muerte como "Caballero sobre el caballo pálido"- surgiendo de la gran abertura zoomórfica; $\left.4^{\circ}\right)$ También resultará frecuente la presencia de las fauces como destino de los derrotados en el tema de la "Caída de los ángeles rebeldes", con la tópica disposición de las fauces infernales en la parte inferior del campo de representación, de modo que los demonios se precipitan en ellas al final de un vertiginoso descenso vertical.

En las siguientes páginas vamos a analizar estos cuatro contextos temáticos de la representación de Leviatán concebido como unas enormes fauces monstruosas que representan la entrada a los infiernos $-\mathrm{O}$, en algunos casos, uno de sus elementos constituyentes- en la iconografía cristiana, tras una introducción sobre el tipo genérico de esta temible figura.

\section{Variantes del tipo de la boca zoomorfa del infierno en la iconografía medieval europea}

\subsection{Las fauces de Leviatán como acceso al infierno, o lugar de tránsito de criaturas demoníacas}

Dentro de categoría icónica más general de la boca de Leviatán que se abre como visión del terrible receptáculo infernal al que son arrastrados, o en el que permanecen eternamente encerrados los condenados, podemos establecer dos categorías principales: aquélla en la que la boca -o cabeza del animal o criatura monstruosa- aparece aislada y descontextualizada, y una segunda que reúne los ejemplos en los que esas fauces se encuentran integradas en una visión escatológica o infernal más amplia y compleja. En ambos casos esta fiera cavidad puede crear una abertura de disposición vertical, como si fuera literalmente una "puerta" por la que los condenados acceden caminando al más allá, o bien como la entrada a un profundo foso o abismo al que son arrojadas las almas perdidas. El aspecto que a veces esta boca llameante adopta como "caldero de castigo" infernal, se subraya con la inclusión entre sus mandíbulas de una verdadera marmita o caldero de cocina dispuesto sobre las llamas en cuyo interior se hacinan los condenados, ilustrativo ejemplo de la frecuente traslación de elementos de la vida cotidiana al mundo de ultratumba.

46 Si bien aparecen ciertas indicaciones del Descenso a los Infiernos en el Nuevo Testamento, su significado estaba aún poco definido; hay que esperar al s. II para que esta creencia sea ampliamente aceptada como explicación de lo que Cristo habría hecho desde su muerte en la cruz, el viernes por la tarde, hasta su resurrección, el domingo por la mañana. De este modo, tras morir, Cristo fue a enfrentarse a sus viejos enemigos: la Muerte y el Diablo. La aceptación teológica de este episodio apócrifo reside en el hecho de que Dios retrasó la Encarnación durante varios siglos después del Pecado original, decisión que podría haber privado a millones de hombres de la posibilidad de salvación sólo por haber vivido y muerto antes de la venida de Cristo. Ante tal injusticia, la comunidad cristiana buscó una manera de extender la salvación a los muertos, permitiendo que Cristo predicara a los que habían muerto previamente, de modo que todos pudieran compartir los efectos expiatorios de su palabra. Vid. Russell, Jeffrey Burton, op. cit., 102-103. 
En relación a la primera posibilidad, el motivo de la Boca del Infierno hace su acto de aparición en la escultura monumental románica en torno al s. XII. Ignoramos si alude concretamente a Leviatán el motivo conservado en uno de los capiteles exteriores de la iglesia colegial de Saint-Pierre (Chauvigny, Francia), formado por una terrorífica boca infernal compuesta mediante la fusión de las fauces de sendos dragones alados y bípedos, adaptándose de forma magistral a las limitaciones del espacio escultórico. Estas mandíbulas dentadas engullen por la cabeza a un condenado desnudo que agita los brazos, abre la boca y saca la lengua en señal de desesperación. Una composición similar se conserva en un capitel de la iglesia románica de SaintGervais y Saint-Protaix de Civaux (Vienne, Francia), en la que un dragón bicorpóreo devora el alma de un condenado al que sujeta con sus dos garras ${ }^{47}$.

Ejemplo ya indudable de esta personificación de Leviatán es la representación esculpida que encontramos en una de las claves del abovedamiento de crucería de la catedral de Saint John the Baptist de Norvich, Inglaterra (el edificio fue finalizado en 1145), donde se disponen, mediante una composición muy ingeniosa pese al escaso espacio disponible, tanto la boca abierta, dotada de grandes colmillos y los tres condenados atrapados en su interior, como el oscuro demonio que obstruye la entrada. La pieza aún conserva gran parte de su policromía original [Fig. 6].

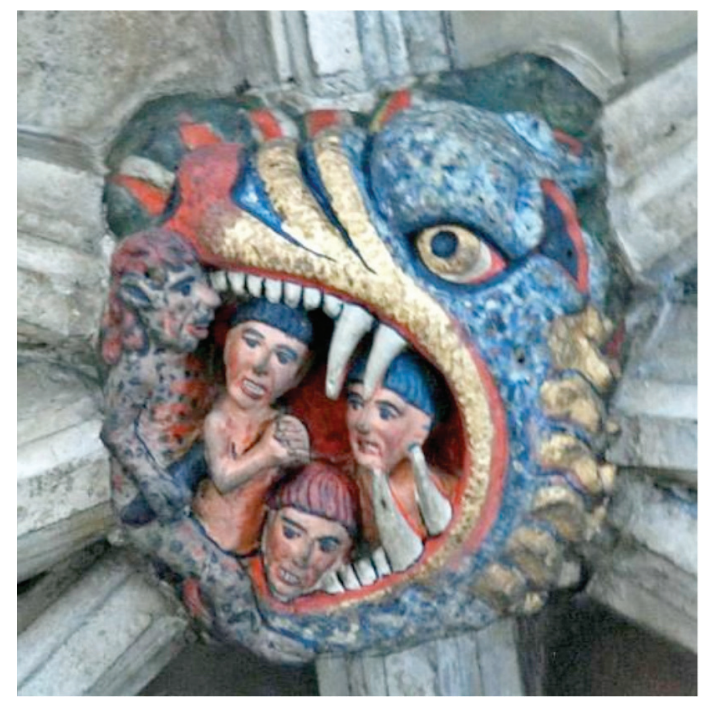

Fig. 6. Demonio y condenados en la boca de Leviatán, ca, 1145. Norvich (Norfolk, Reino Unido), catedral de Saint John the Baptist, clave de bóveda de crucería.

$47 \quad$ El tema del monstruo antropófago o devorador de seres humanos se encuentra muy extendido en la escultura románica europea. Mencionemos, entre otros ejemplos, el león tragando a un hombre en el tímpano de Stangby (Museo Histórico de Lund, Suecia); Jonás arrojado de un barco y tragado por una ballena en una arquivolta de la portada oeste de la iglesia del monasterio de Ripoll (Gerona); la cabeza de león engullendo a un hombre en el tímpano de la iglesia de Livinhac (Aveyron, Francia); o grifo y león devorando sendas cabezas en el tímpano norte de la catedral de Lund (Suecia). Vid. Champeaux, Gérard de y Sterckx, Dom Sébastien (1985), Introducción a los símbolos, Madrid, Encuentro, 350 y ss. Para el caso español, Ma Esperanza Aragonés Estella -op. cit., 115-127-, hace un completo análisis de las "ménsulas" o "máscaras devoradoras" -normalmente con rasgos de león-o de los leones infernales andrófagos situados en las portadas dentro del ámbito de la escultura románica navarra, con ejemplos en templos de Pamplona, Gazólaz, Otazu, Sangüesa o Estella. 
Uno de los modelos más difundidos del Leviatán medieval por su atractiva resolución formal es el que un miniaturista inglés anónimo llevó a cabo para el Salterio de Winchester (Londres, British Library, ms Cotton Nero C. IV, f. 39r, ca. 1150), en el que un ángel cierra con llave las puertas del Infierno conforme a las descripciones apocalípticas ( $A p$ 20,1-3). Las mandíbulas de la bestia se despliegan divididas en dos partes simétricas al adaptar la máscara tridimensional a la superficie del plano; para incrementar su carácter monstruoso, de la gran cabeza surgen otras testas secundarias de dragón, destinadas a cubrir los espacios vacíos de la viñeta. En su interior, los demonios someten a torturas y penalidades a condenados de toda condición social [Fig. 7]. También en un detalle de la decoración de la tribuna del coro de la iglesia abacial de Klosterneuburg (cerca de Viena, Austria), formada por placas de cobre esmaltadas con escenas inspiradas en De civitate Dei de san Agustín o en los sermones de Honorio de Autun, realizados por Nicolas de Verdun en 1180, encontramos una boca draconiana del averno. Colocada en disposición vertical, un demonio introduce en ella a un condenado al que transporta ensartado en una horca; otros réprobos, algunos con identificativos eclesiásticos, ya penan entre las llamas [Fig. 8].

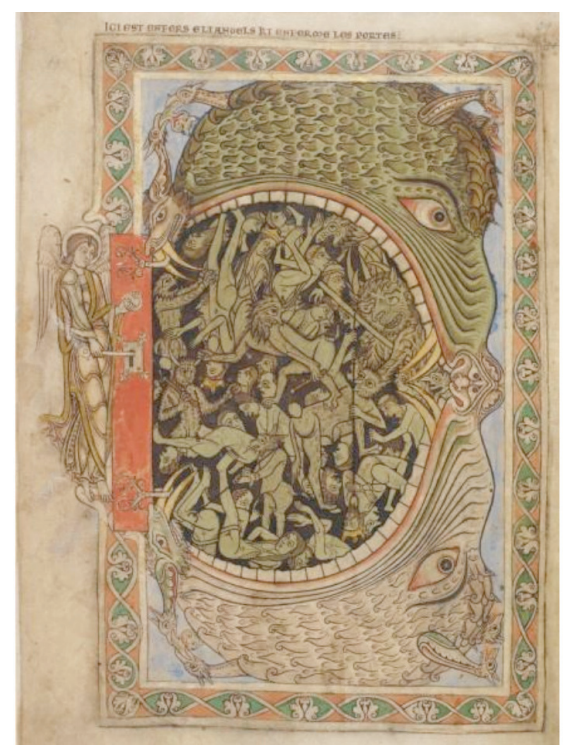

Fig. 7. Un ángel cierra las puertas del infierno con una llave, Salterio de Winchester, manuscrito, ca. 1150. Londres, British Library, ms Cotton Nero c. IV, f. 39r.

Si contemplamos ahora una de las ilustraciones del Tanner Apocalypse, manuscrito inglés de hacia 1250-55 (Oxford, Bodleian Library, ms Tanner 184, f. 72), podemos observar a un demonio que arroja al dragón del Apocalipsis, tras su derrota definitiva, en una fosa representada como una gran boca felina, de la que surgen partes de otras bestias demoníacas. En algunos casos, los artistas desdoblaron las cabezas de Leviatán, desarrollando así la idea que ya estaba implícita en la ilustración descrita del Salterio de Winchester, con el fin de acentuar el carácter monstruoso y fantástico de la criatura, o sencillamente para lograr un más amplio espacio representacional en el que poder incluir un mayor número de personajes. Así sucede en un Apocalipsis 
iluminado procedente del norte de Francia y fechado en el s. XIII (Biblioteca municipal de Cambrai, ms 422, f. 95v), en el que la figura se desdobla en dos grandes cabezas leoninas con cuernos, entre las cuales, a modo de boca común, queda un espacio oscuro, no demasiado bien definido, que constituye la entrada al inframundo. En su interior, aparte de varios condenados sufrientes, pueden contemplarse diversas bestias apocalípticas, entre ellas el dragón rojo de siete cabezas. Un demonio con aspecto de sátiro, armado con una vara, parece vigilar para que nadie escape de tan feroz cavidad. Mejor resuelto que el anterior es el diseño similar que encontramos en otro Apocalipsis glosado en francés de la Bibliothèque nationale de France (ms fr. 403, f. 40r, 1240-50). Aquí también observamos una doble cabeza cornuda, cuya boca común se abre para mostrarnos una caótica acumulación de demonios y condenados, entre los que resulta bien visible una grotesca criatura que clava sus horcas en bestias apocalípticas como el dragón de siete cabezas, o la hidra de la ramera de Babilonia (Ap 17) [Fig. 9]. Finalmente, la boca se hace triple en una ilustración similar a las anteriormente descritas en el Lambeth Apocalypse (Londres, Lambeth Palace Library, ms 209, f. 36v, ca. 1260). El modelo mantiene su vigencia en los ss. XIV y XV. Un ejemplo singular de ello por su disposición son las fauces infernales esculpidas que se abren en la predela del retablo pétreo de la capilla axial de Notre-Dame-de-Bethléem, en la catedral de Saint-Just et Saint-Pasteur de Narbona (s. XIV), bajo la imagen de la citada Virgen: en el interior de tan temible receptáculo, concebido como una especie de cueva, aparece el Diablo entronizado como rey del averno, rodeado de condenados y flanqueado por dos grandes calderos sobre las llamas con sendas almas atormentadas en su interior [Fig. 10]. El Museo de Berry (Bourges, Francia) conserva un fragmento esculpido con La Boca del Infierno de comienzos del s. XV. En este ejemplar, con aspecto de cabeza de lobo con cuernos, situada sobre las llamas, se disponen dos cuerpos de condenados dentro de su boca a punto de ser engullidos. Sobre la pieza aún persisten restos muy fragmentados de demonios.

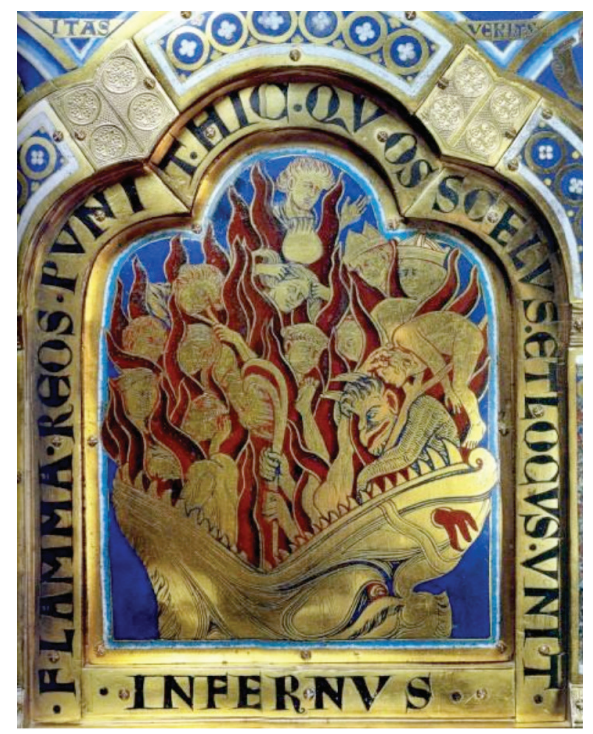

Fig. 8. Nicolas de Verdun, escena infernal en la boca de Leviatán, placa de cobre esmaltada, 1180. Klosterneuburg (Austria), iglesia abacial, tribuna del coro. 


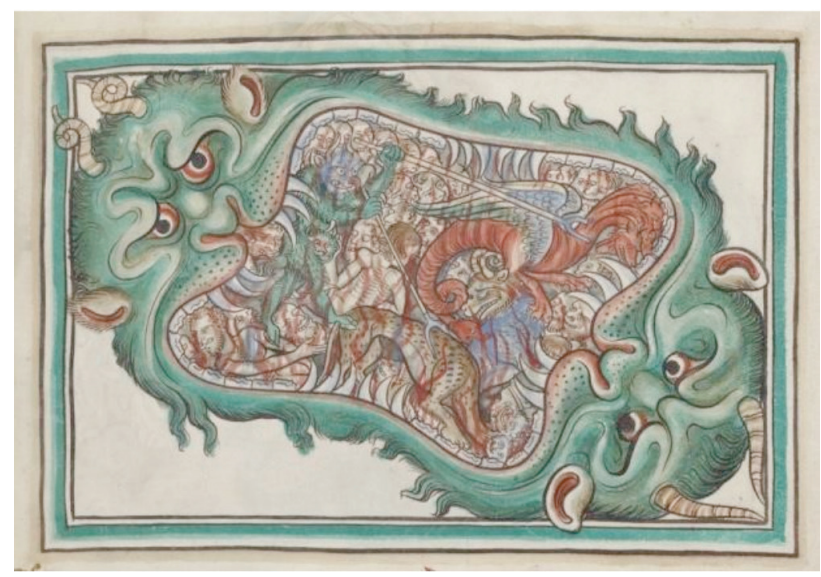

Fig. 9. Infierno como doble cabeza de Leviatán, Apocalipsis glosado en francés, manuscrito, 1240-50. París, Bibliothèque nationale de France, ms fr. 403, f. 40r.

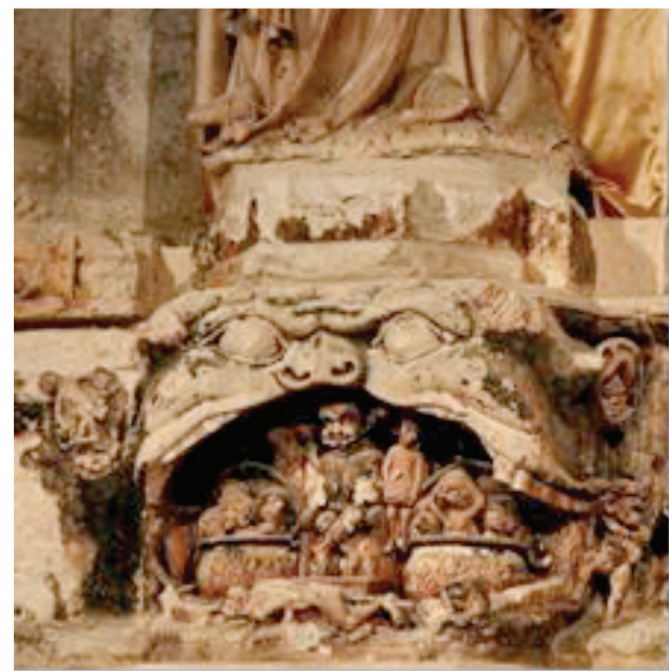

Fig. 10. Infierno en el interior de la boca de Leviatán, s. XIV. Narbona (Francia), catedral de Saint-Just et Saint-Pasteur, capilla de Notre-Dame-de-Bethléem, predela del retablo pétreo.

Los ejemplos menudean en la escultura y pintura murales inglesas de finales de la Edad Media. Junto a su incorporación a diversas representaciones del Juicio final, encontramos un ejemplo de cabeza "individualizada" en el relieve conservado en un friso esculpido del interior de la Rosslyn Chapel, al sur de Edimburgo, en Escocia (s. XV). La escena que representa es interesante por su ingenuismo: un demonio que surge de Leviatán, situado en el extremo derecho del friso, se dispone a "enganchar" con su rebañadera a un par de amantes, aparentemente ilícitos, que se abrazan y están a punto de besarse.

A veces la enorme boca infernal se abre sencillamente para permitirnos visualizar las terribles calamidades que tienen lugar en su cavidad. Podemos mencionar dos 
ilustrativos ejemplos de ello en la miniatura medieval, uno de inicios del s. XIII, y el segundo perteneciente a las décadas centrales del s. XV. El primero constituye la representación del Juicio final del códice del Beato conservado en el monasterio de San Andrés de Arroyo, Palencia (París, Bibliothèque nationale de France, Nouv. acq. lat. 2290, f. 160r, ca. 1220); en el registro intermedio de la ilustración un demonio arrastra hacia el infierno, atados con una cuerda, a un grupo de condenados que, a juzgar por su indumentaria y atributos, pertenecen a una elevada posición social -reyes, eclesiásticos, aristócratas...-; son conducidos hacia un averno dispuesto en el nivel inferior en forma de enorme boca zoomorfa invertida, dentro de la cual, entre las llamas, sendos demonios amenazan con sus agarraderas a un grupo de hombres ya desnudos, y a otros que giran amarrados a una rueda de tortura, tipo de suplicio cuya representación no resulta habitual en estos contextos.

Por su parte, en una ilustración del Livre de la Vigne de Nostre Seigneur (Oxford, Bodleian Library, ms Douce 134, f. 81v, ca. 1450-70), tratado edificante sobre temas como el Anticristo, el Juicio final, el Cielo o el Infierno, una boca de Leviatán se abre desmesuradamente hasta desdoblarse en dos partes simétricas y afrontadas, para mostrarnos en su interior a un interesante grupo de demonios antropomorfos y zoomorfos - estos últimos con morfología de serpientes aladas o dragones- martirizando a sus cautivos; el más singular iconográficamente es el que presenta aspecto de centauro y cuernos de íbice, que sujeta una rebañadera mientras pisotea con sus cascos a un par de condenados tendidos bajo él [Fig. 11].

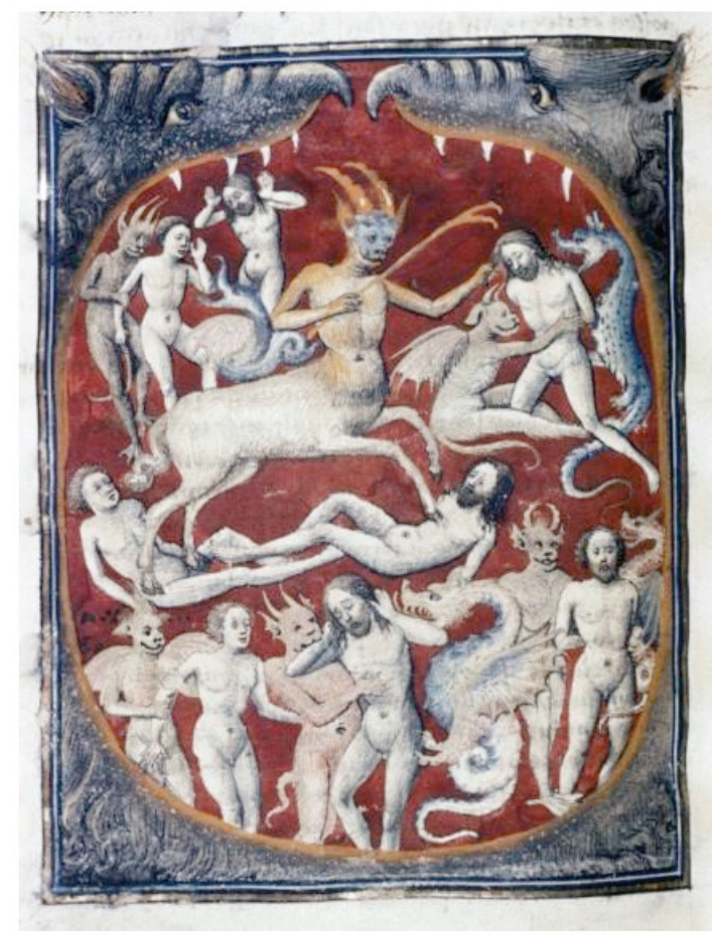

Fig. 11. Centauro diabólico castigando a los condenados en la boca del infierno, Livre de la vigne de Nostre Seigneur, manuscrito, ca. 1450-70. Oxford, Bodleian Library, ms Douce 134, f. 81v. 
En el tránsito del s. XV a XVI van a proliferar las ilustraciones xilográficas en las que la gran apertura de la boca del inframundo permite contemplar una escena infernal donde los demonios se complacen en todo tipo de atrocidades con sus indefensas víctimas, en una especie de caos organizado y claustrofóbico.

En otras ocasiones, la temible figura se anima con la incorporación de personajes demoníacos que desempeñan funciones más concretas o específicas que las de arrastrar a los condenados al interior del averno. Así, en ciertos momentos, resulta posible encontrar a Lucifer como vigilante de la monstruosa entrada al más allá, una suerte de "Cerbero diabólico" que se dispone sobre o junto a la monstruosa boca llameante de Leviatán, a veces encadenado a ella, "supervisando" la entrada de condenados en el foso del inframundo. Un ejemplo representativo es el procedente de una miniatura del Misal de Poitiers ${ }^{48}$ : aquí Satanás aparece como ser de acentuado aspecto monstruoso, con un feroz rostro leonino dotado de cuernos, colmillos, largas orejas colgantes y barbas, gastrocéfalo -sendas serpientes surgen de esta boca abdominal en cuyo interior ardiente se aprecian pequeños demonios-, con articulaciones con formas de cabezas de animales y con la piel escamada, que se encuentra firmemente encadenado a las draconianas fauces del Infierno, donde se recluyen las almas sufrientes de los réprobos. Porta un triple garfio a modo de cetro de monarca del abismo.

Una segunda variante vendría constituida por un tipo icónico protagonizado por la figura de un demonio - presumiblemente Lucifer o Satanás- atado a un soporte en forma de columna que resulta visible en el interior de las moradas infernales, en un contrapunto grotesco de la imagen de Jesús amarrado a la columna para recibir los latigazos al inicio de su Pasión. Una iluminación del Juicio final contenida en el Salterio del convento dominico de St Katharinental en Zúrich, Suiza (Schweizerisches Landesmuseum, ms 314, f. 153v) nos ofrece un curioso infierno en el ángulo inferior derecho: en el interior de una cueva, rodeada de pequeñas oquedades u hornacinas en las que arden bustos de varias almas pecadoras, vemos a un estilizado demonio cornudo y negro, de ojos saltones, amarrado a una columna central como única "ambientación" del averno. En un manuscrito alemán del s. XV ${ }^{49}$, en el interior de una "Boca del Infierno", podemos observar a un grupo de demonios reunidos en "consejo" en torno a uno de ellos, atado por los brazos y las piernas a una columna que hace, al mismo tiempo, las funciones de soporte de las fauces abiertas; este elemento de "sujeción" permite pensar en los mecanismos utilizados en los autos sacramentales, en los que se empleaban estas cabezas mecánicas de Leviatán para simular de forma dramática la entrada a las profundidades infernales. Una escena similar puede contemplarse en una de las ilustraciones de Das buch Belial -el Libro de Belial- de Jacobo de Téramo, tanto en las versiones manuscritas del s. XV como en las impresas, que arrancan de la editio princeps de Augsburgo, 1473. En un panel al fresco en el muro interior del testero occidental de la iglesia de Saint Martin, en Sillegny (tránsito del s. XV al XVI), un gran diablo cornudo, rojo y negro, armado con una gran rebañadera, contempla toda la escena del Juicio final sentado y encadenado por el cuello a una columna, mientras sus colaboradores llevan a las almas condenadas

48 Vid. Didron, Adolphe N. (1965), Christian Iconography. The History of Christian Art in the Middle Ages, Nueva York, Frederick Ungar Publishing, vol. II, 118-119, fig. 171. Pensamos que el manuscrito al que se refiere este autor es el Nouailher Missal, conservado en el Tesoro de la catedral de Poitiers.

49 La referencia procede de Turner, Alice K. (1995), History of Hell, San Diego/Nueva York/Londres, A Harvest Book, 118, donde la imagen carece de créditos. 
empaladas o en carretilla hacia las fauces ardientes, que presentan un rostro de rasgos similares a los del propio Lucifer [Fig. 12].

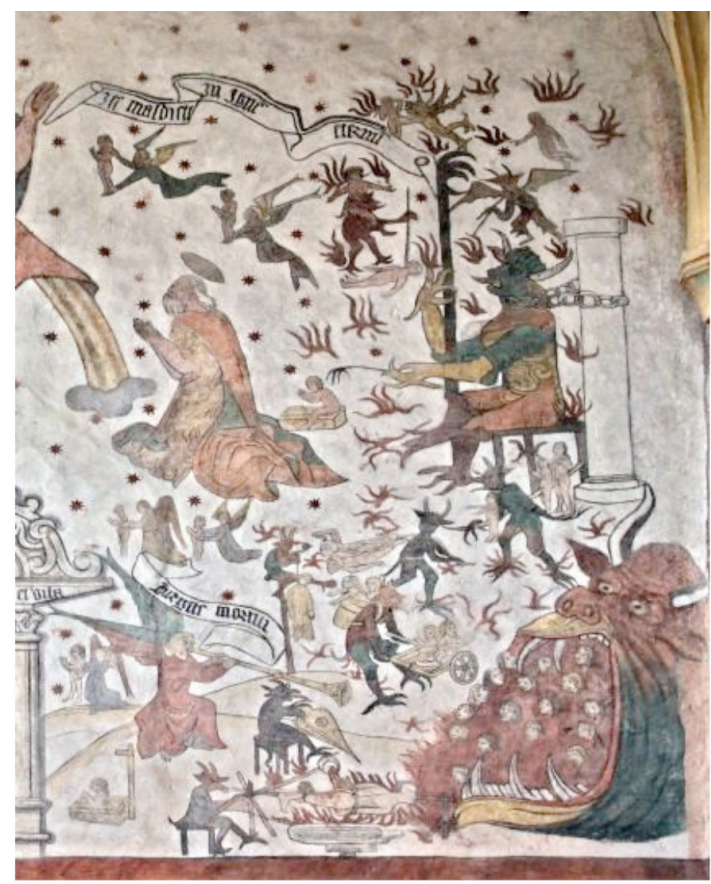

Fig. 12. Demonios arrastrando a los condenados en la boca del infierno en presencia de Lucifer, detalle del Juicio final, fresco, ss. XV-XVI. Sillegny (Francia), iglesia de Saint Martin, testero interior occidental.

En tercer lugar, las fauces abiertas pueden ser el lugar empleado, en aquellas imágenes de intención más anecdótica o narrativa, como umbral de paso habitual de los demonios en su entrada o salida en el Infierno. Así lo encontramos en otra obra del ya mencionado obispo Jacobo de Téramo titulada Consolatio peccatorum o Processus Luciferi contra Jesum Christum -tratado en el que se recrea una disputa entre el Diablo y Jesucristo, consistente en la demanda que Lucifer hace a éste por haber infringido los derechos de su propiedad descendiendo al averno-, tanto en las diversas versiones manuscritas que vieron la luz a lo largo del s. XV (mencionemos como ejemplos las de Salzburgo, Universitätsbibliothek, Cod. theol. et phil., 195, f. 27r, 1401 [Fig. 13]; Karlsruhe, Badische Landesbibliothek, codex St. Peter, pap. 36, f. 31v, segunda mitad del s. XV; o Heidelberg, Universitätsbibliothek, Cod. Sal. VII, 114, f. 89r, ca. 1460r), como en las ediciones ya impresas de la misma (Das buch Belial, Augsburgo, 1473). En una de las ilustraciones comunes, titulada "El demonio Belial delante de las puertas del Infierno", este diablo aparece haciendo una consulta a sus compañeros demoníacos - comunitate dyabolica- ante las puertas llameantes del infierno, donde se destaca la figura de uno de ellos -Lucifer- que escucha a Belial mientras permanece amarrado a una columna que parece actuar como elemento que mantiene abiertas las fauces mientras se desarrolla el consilium. 


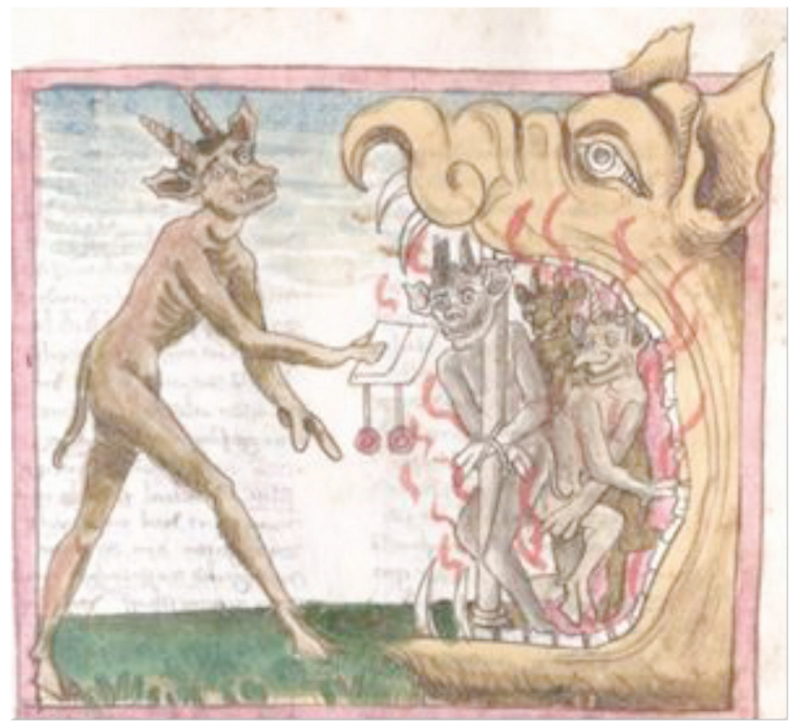

Fig. 13. Encuentro de Belial y Lucifer en la puerta del infierno, manuscrito, 1401. Salzburgo, Universitätsbibliothek, Cod. theol. et phil., 195, f. $27 \mathrm{r}$.

\subsection{Leviatán como boca monstruosa de entrada al infierno situada en un paraje infernal o en representaciones apocalípticas y del Juicio final}

Como hemos indicado más arriba, la cabeza de Leviatán con sus fauces ígneas abiertas aparece en ciertas ocasiones "contextualizada", incluyéndose como un elemento escenográfico más que forma parte de la ambientación general de determinados parajes infernales: es un complemento entre fantástico y temible que ayuda a componer la geografía de este desolado y espantable lugar. De ello debemos deducir que, en estos casos, la terrible cabeza no ejerce realmente como umbral de acceso al inframundo -y, por tanto, su función es diferente al del resto de figuras similares que estamos mencionando en el presente trabajo-. Se trata más bien de una suerte de "gruta animada" o "cámara de los horrores", un receptáculo con apariencia bestial o, en los ejemplos más avanzados, incluso humanoide, y en cuya cavidad bucal son deglutidas las almas de los condenados y sometidas a los más inimaginables suplicios. Como ejemplo temprano mencionemos una máscara infernal que devora el alma de un rico malvado con ayuda de algunos demonios vestidos con faldellín en la Anastasis del pórtico de la basílica de San Prudencio de Armentia, en Álava, fechada en el s. XIII [Fig. 14].

Pero donde encontramos los ejemplos más numerosos y sugerentes es en la miniatura libresca de finales de la Edad Media. Así, el artista flamenco Simon Marmion, en la "Visión del Infierno" que forma parte de una versión manuscrita de la Visio Tnugdali -Las visiones del caballero Tnugdalus o Tundale-(Los Ángeles, The J. Paul Getty Museum, ms 30, f. 17r, 1475), representa a un ángel que va mostrando al alma desnuda del personaje protagonista distintos aspectos del mundo infernal. De acuerdo con la descripción de este viaje imaginario, la boca de la bestia Acheron es comparable en su tamaño a una montaña; en su interior, donde resulta visible la lengua, se puede intuir a varios réprobos en medio de un intenso resplandor rojo similar al de un horno. Dos per- 
sonajes estilizados de color negro, uno de ellos dispuesto al derecho y otro del revés, mantienen abierta, a modo de "atlantes", esta gran boca mientras alrededor del monstruo son visibles algunos demonios [Fig. 15]. El Infierno de un Libro de horas de hacia 1480 (Londres, Victoria and Albert Museum, ms Salting 1221, f. 153r), representación sin duda inspirada en la literatura visionaria -Visiones de Pablo o la ya mencionada de Tundale- o en los Diálogos de Gregorio Magno, incluye una tenebrosa boca infernal en el fondo del abismo, a modo de un gran hocico de puerco, que proyecta un chorro de llamas mezcladas con algunas almas de réprobos. En otras ocasiones, la composición se centra en la actividad de los demonios que, inmisericordes, arrojan a las almas desnudas en el interior de la boca, como es el caso de una letra capital de la Table de la foi chrétienne, realizada por los Maestros de Dirc van Delf, activos en Utrecht, Holanda (Nueva York, Pierpont Morgan Library, ms M.691, f. 200v, ca. 1405-10).

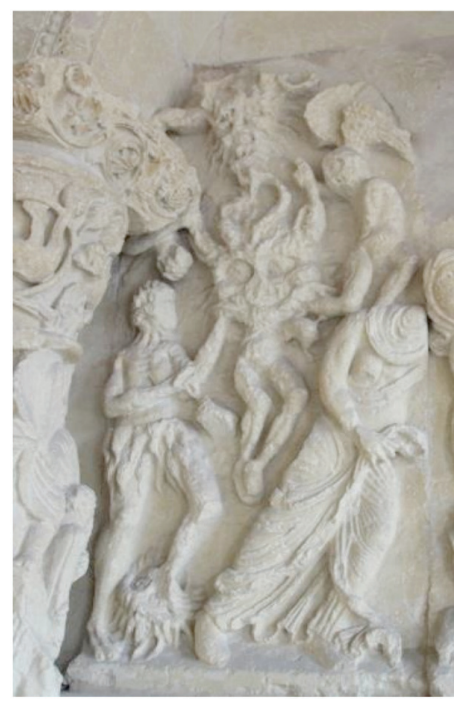

Fig. 14. Una máscara infernal devora el alma de un rico malvado, detalle de una Anastasis, s. XIII. Armentia (Álava), basílica de San Prudencio, pórtico.

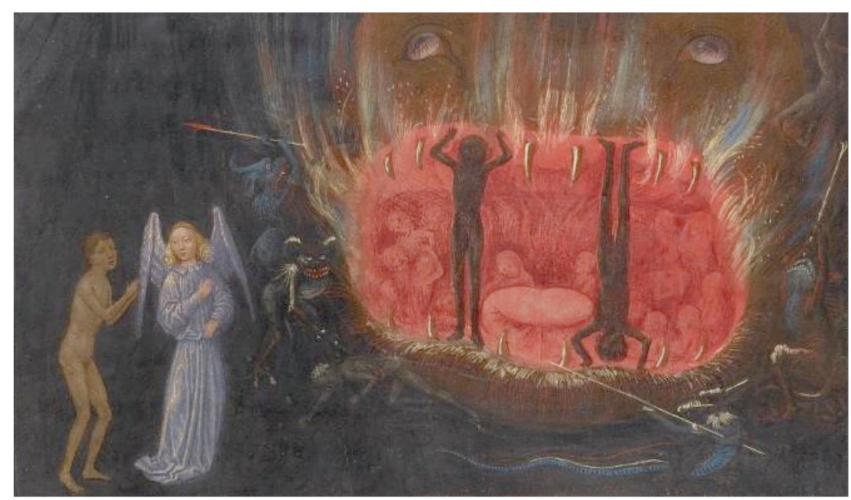

Fig. 15. Simon Marmion, "Visión del infierno", Visio Tnugdali, manuscrito, 1475. Los Ángeles, The J. Paul Getty Museum, ms 30, f. 17r. 
Ambas posibilidades las encontramos reunidas en las ilustraciones a página completa del Apocalipsis flamenco iluminado hacia 1400 (París, Bibliothèque nationale de France, ms néerl. 3): en la lámina 17 encontramos a las enormes fauces ardientes como lugar del que surgen las almas desnudas en el momento del juicio definitivo para postrarse ante Cristo Juez, y, en la lámina 22, un demonio escarlata arroja en su interior a las bestias apocalípticas entre varios condenados sufrientes [Fig. 16]. Una versión más anecdótica nos la ofrece el Juicio final del Holkham Bible Picture Book (Londres, British Library, Add. ms 47682, f. 42, segundo cuarto del s. XIV), donde los demonios transportan en carretilla a los condenados hacia sendos calderos situados sobre la boca del inframundo. También en una miniatura del Libro de Horas de Catalina de Cleves, duquesa de Guelders (Nueva York, Pierpont Morgan Library, ms 945 , f. $168 \mathrm{v}$, ca. 1440) nos encontramos ante un impresionante Leviatán que abre una boca de textura membranosa para mostrar en su interior un segundo rostro sobrehumano de color rojo, en cuyas fauces ardientes los demonios cuecen a los ímprobos en un caldero. Tan terrible cavidad se sitúa al pie de un infierno concebido como un siniestro castillo, decorado con calaveras y grandes marmitas que se calientan sobre las torres. La parte superior de la fortaleza presenta otra boca monstruosa integrada en la arquitectura del edificio ${ }^{50}$. Según Monique Blanc ${ }^{51}$, esta delirante visión es una prefiguración surrealista de las visiones "bosquianas" del infierno en los detalles de las diferentes torturas y suplicios. En cuanto al ámbito de pintura sobre tabla, Hans Memling nos ofrece una ilustración del "Infierno" en el panel derecho del Tríptico de la vanidad terrenal y de la redención celeste (Estrasburgo, Museo de Bellas Artes, ca. 1485), en la que un demonio gastrocéfalo de mirada alucinada se sitúa sobre los condenados, que se precipitan en el interior de la ardiente boca de Leviatán, encajada en el seno de un abismo rocoso; sobre todo ello aparece inscrita en una filacteria volada la terrible sentencia IN INFERNO NULLA EST REDEMPTIO [Fig. 17]. También El Bosco incluyó en la tabla central de una de las versiones de las Tentaciones de san Antonio Abad del Museo del Prado (ca. 1510-15) un inquietante Leviatán que surge de una cavidad al pie de unas rocas, dotado del aspecto de una llamativa y gesticulante cabeza humanoide con brazos - una de sus manos sujeta una gran cuchara-, y con ciertos detalles exagerados, alterados o grotescos, en especial la propia boca y la lengua saliente, que se convertirá, aunque con variaciones, en un auténtico tópico en las representaciones "infernales" del taller y numerosos seguidores del pintor flamenco.

Por otra parte, y de manera algo más precisa, no son infrecuentes los ejemplos artísticos en los que el monstruoso Leviatán se incorpora a las ya por lo general complejas composiciones del Juicio final, donde, dispuesto de manera habitual en el ángulo inferior derecho -a la izquierda, por tanto, del trono del Hijo del hombre si seguimos a $M t 25,31$ y ss-, donde aparece como una fuerza poderosa y primitiva, un habitante de la oscuridad que abre sus mandíbulas ardientes para engullir a las almas condenadas que los demonios empujan o trasladan hasta ella. El motivo gozará de una amplísima difusión en todos los medios plásticos hasta finales de Edad

50 En el teatro medieval a menudo se recurre a una Boca del Infierno como artilugio mecánico usado para asombrar a los espectadores mediante una vívida y dramática representación de la entrada al inframundo, en muchas ocasiones caracterizada como acceso a un castillo fortificado. Ésta no es la única boca infernal incluida en este conocido manuscrito: en otras ilustraciones de menor tamaño que la anterior, encontramos diversas cabezas "infernales" con un diseño similar pero más simplificado que el Leviatán descrito con anterioridad, en las que, además de los condenados, pueden observarse ángeles que conversan con ellos, o les ayudan a escapar de tan aterradora prisión.

51 Op. cit., p. 39. 
Media $^{52}$, contando con algunos testimonios más tardíos durante el quinientos, en los que se incluyen diversos impresos populares generados en el ámbito de la polémica religiosa protestante, en imágenes en las que determinadas personalidades clericales del bando católico son tragadas por la Boca del Infierno ${ }^{53}$.

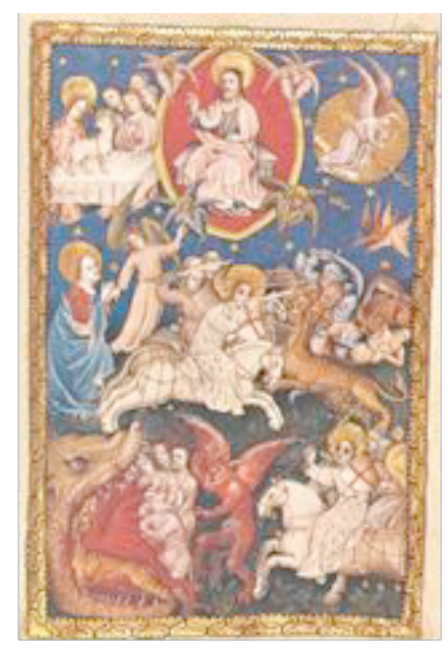

Fig. 16. "El caballero fiel y verídico abatiendo a las bestias", Apocalipsis flamenco iluminado, ca. 1400. París, Bibliothèque nationale de France, ms néerl. 3, lámina 22.

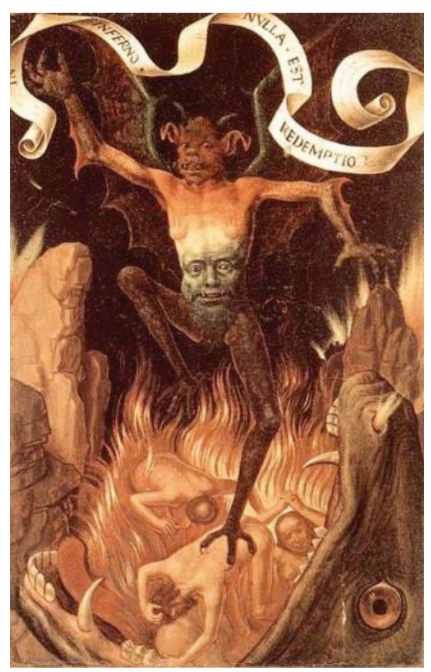

Fig. 17. Hans Memling, "Infierno", Tríptico de la vanidad terrestre y de la redención, panel derecho, ca. 1485-1490. Estrasburgo, Museo de Bellas Artes.

52 Sobre esta cuestión, vid. los numerosos ejemplos recogidos en el trabajo de Schmidt, Gary D. (1995), The Iconography of the Mouth of Hell: Eighth-Century Britain to the Fifteenth Century, Selinsgrove, PA, Susquehanna University Press.

53 Lehner, Ernst y Lehner, Johanna (1971), Picture Book of Devils, Demons and Witchcraft, Nueva York, Dover, 166, fig. 232. 
Podemos ya encontrar ejemplos representativos en la escultura románica: una ingenua boca con grandes colmillos y cabellos en punta aparece representada en relieve en el dintel del tímpano de la portada sur de la iglesia de Perse en Aveyron (Languedoc-Roussillon-Midi- Pyrénées, Francia), fechable en el s. XII, formando parte de la composición titulada El infierno y el cielo; de igual modo, la boca de un dragón aparece, asomando por la puerta "arquitectónica" abierta que constituye claramente la entrada al reino que preside Lucifer, en el ángulo inferior derecho del tímpano del Juicio final (ca. 1105-1110) del portal oeste de la iglesia abacial de Sainte-Foy de Conques [Fig. 18] ${ }^{54}$. También podemos contemplarla en el tímpano esculpido dedicado a este tema perteneciente a la portada de Santa María la Real de Sangüesa (Navarra): en el extremo derecho de este espacio se abre la gran boca dentada orientada hacia arriba, disponiéndose sobre ella un grupo de condenados. Dos de ellos, hombre y mujer, se presentan de cuerpo entero, con serpientes que muerden sus pechos en probable alusión a la lujuria; el resto del conjunto adquiere el singular aspecto de tres series de máscaras superpuestas, con el pelo llameante y las bocas abiertas en gesto sufriente ${ }^{55}$. De igual modo, por mencionar un ejemplo más, en el tímpano esculpido de la fachada de la basílica de Sainte-Marie-Madeleine de Vézelay, aparece un estilizado Leviatán abierto en el extremo derecho dispuesto a engullir a los pecadores dispuestos en fila.

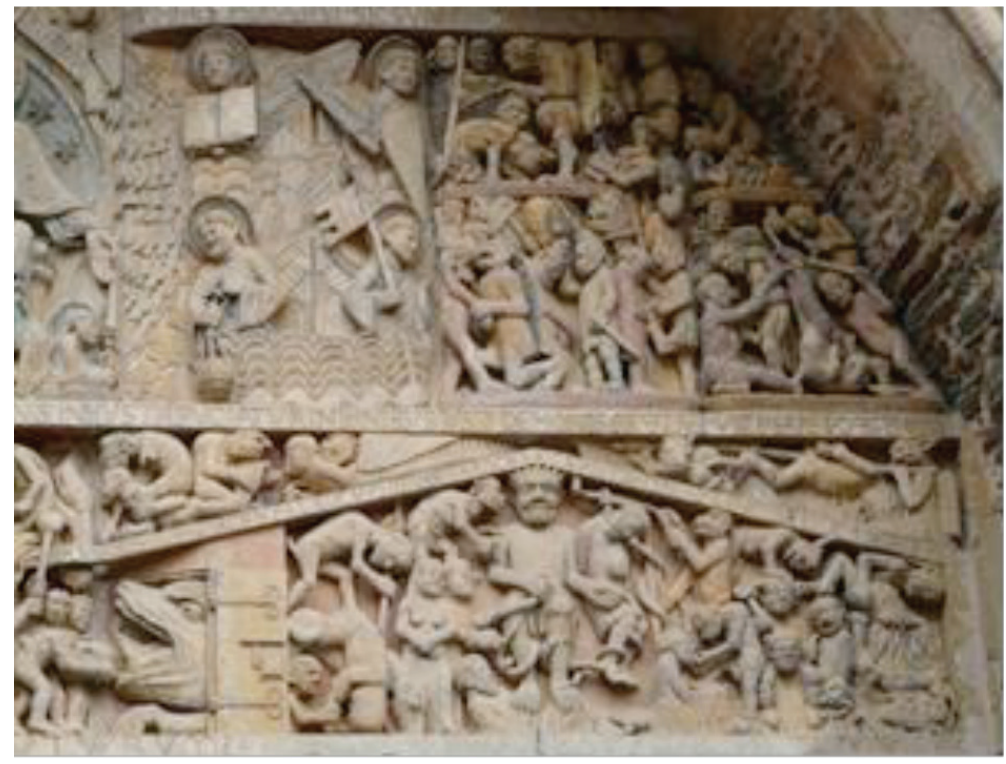

Fig. 18. "Infierno", detalle del Juicio final, ca. 1105-1110, Conques (Francia), abadía de Sainte-Foy, detalle del tímpano de la portada oeste.

54 Bousquet, Louis J. (1948), Le jugement dernier au tympan de l'église de Sainte-Foy de Conques, Rodez, Imp. P. Carrere.

$55 \quad \mathrm{M}^{\mathrm{a}}$ Esperanza Aragonés - op. cit., 56-58- singulariza, entre estas máscaras de almas condenadas y dolientes, a dos que pueden representar a entes demoníacos, dispuestas a ambos lados de las fauces de Leviatán: una de ellas de mayor tamaño, con cuernos, situada sobre los condenados, de cuya boca dentada surgen las mencionadas serpientes; y otra, en el ángulo inferior derecho, que saca la lengua conforme a la típica actitud burlona atribuida con frecuencia los diablos. 
La fórmula se mantiene en la estatuaria gótica, como podemos comprobar en el Infierno (ca. 1210-15) del portal central sur con el Juicio final de la catedral francesa de la Assomption de Notre-Dame de Chartres, donde unos prelados resignados se disponen a ser engullidos por la boca de Leviatán, situada en uno de los ángulos, de cuyo interior surgen demonios y otros condenados [Fig. 19]. De un modo similar, en el extremo derecho de la escena del pesaje de las almas, friso esculpido bajo el tímpano con el mismo asunto del Juicio final de la también francesa catedral de SaintÉtienne, en Bourges (ca. 1250, conjunto restaurado en el s. XIX), encontramos la monstruosa boca infernal, en cuyo interior los seres malignos arrojan a los réprobos que empujan o llevan sobre sus brazos. Dispuestas en posición vertical, las fauces presentan sobre ellas un caldero repleto de condenados que calientan con sus llamas alentadas por dos demonios laterales que se sirven para ello de fuelles. También en un detalle de una vidriera de dicha catedral, fechada en el s. XII, contemplamos una vez más el motivo de la boca dentro de una representación general del Juicio.

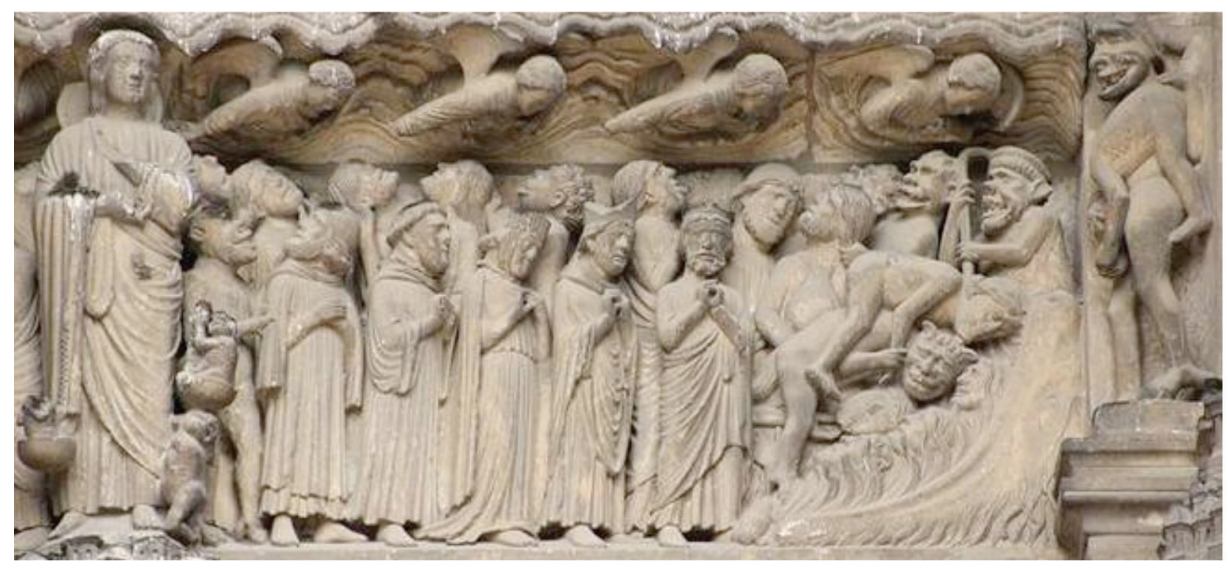

Fig. 19. Condenados siendo conducidos al infierno por los demonios, detalle del Juicio final, ca. 1230. Bourges (Francia), catedral de Saint-Étienne, tímpano del Juicio final, portal oeste.

En la catedral de Santa María, o Catedral Vieja de Salamanca, Nicolás Delli, más conocido como Nicolás Florentino, pintó al fresco en el cascarón del ábside, en torno a 1445, una interesante versión del asunto escatológico que nos ocupa. A la izquierda del monumental Cristo que preside la composición, contemplamos a los condenados, desnudos, entre los que se distinguen algunos eclesiásticos, avanzando atropelladamente hacia la boca de un monstruo reptilíneo de color verde y con enormes colmillos [Fig. 20].

Junto a la escultura y pintura monumental románicas y góticas, la miniatura será uno de los géneros en los que localicemos un mayor número de plasmaciones gráficas de este tema insertas en escenas escatológicas. Un temprano ejemplo es la imagen sintética del Juicio final incluida en el Salterio de Amiens (Amiens, Bibliothèque Métropole, ms 19, f. 12, finales del s. XI), donde un demonio arrastra con una correa a los condenados que salen de sus sepulcros al interior de un Leviatán azul con sus fauces abiertas hacia la parte superior, similar a un gran caldero ardiente. En el Salte- 
rio de Blanca de Castilla (París, Bibliothèque de 1'Arsenal, ms 1186, f. 171v, inicios del s. XIII), en contraste con una insólita visión del Paraíso formada por la figura de Abraham manteniendo en su seno las almas de los elegidos, encontramos el Infierno constituido por la figura de un gran Leviatán circular que, en medio de la asamblea de los condenados, sustenta un gran caldero en el que pena un grupo de réprobos fustigados o mordidos por grotescos demonios [Fig. 21]. En otro manuscrito del segundo cuarto del s. XIII, el Trinity College Apocalypse (Cambridge, Cambridge Trinity College ms R 162, f. 25v, ca. 1242-50), formando parte una vez más del Juicio final, contemplamos las mandíbulas de las grandes fauces de la bestia, en las que se debaten réprobos y demonios en dinámicas composiciones, que se dilatan hasta abarcar toda la anchura del registro inferior ${ }^{56}$. También una ilustración del Bedford Book of Hours (Londres, British Library Add. ms 18850, f. 157r, ca. 1410-30) nos retrata a Leviatán como una feroz boca de dragón "encajada" en el suelo en clara alusión a su condición de entrada al Infierno, rodeada de reptiles y anfibios malignos. Demonios oscuros, con sus manos o con la ayuda de agarraderas, arrojan a los condenados desnudos a su ardiente interior. No puede faltar aquí mención a una de las magníficas ilustraciones de Les très riches heures du duc de Berry (Musée Condé, Chantilly, ms 65, f. 34r, 1415) en la que los hermanos Paul, Jean y Herman Limbourg plasmaron una elegante y simplificada versión del juicio universal -Cristo Juez-donde el Infierno se reduce a las fauces ardientes y humeantes de Leviatán, en el ángulo inferior derecho, conteniendo a algunos cautivos en su interior [Fig. 22]. En otro Juicio final, ilustración ahora de sendos manuscritos de la traducción de Raoul de Presles del De civitate Dei de Agustín de Hipona (París, Bibliothèque nationale de France, ms fr. 22912 f. 2v, ca. 1376; París, Bibliothèque nationale de France, ms fr. 22913 f. 370r, ca. 1370-80), en la entrada de la boca del Averno se dispone un caldero, en cuyo interior se hacinan los réprobos, algunos de los cuales muestran coronas reales, acosados por demonios.

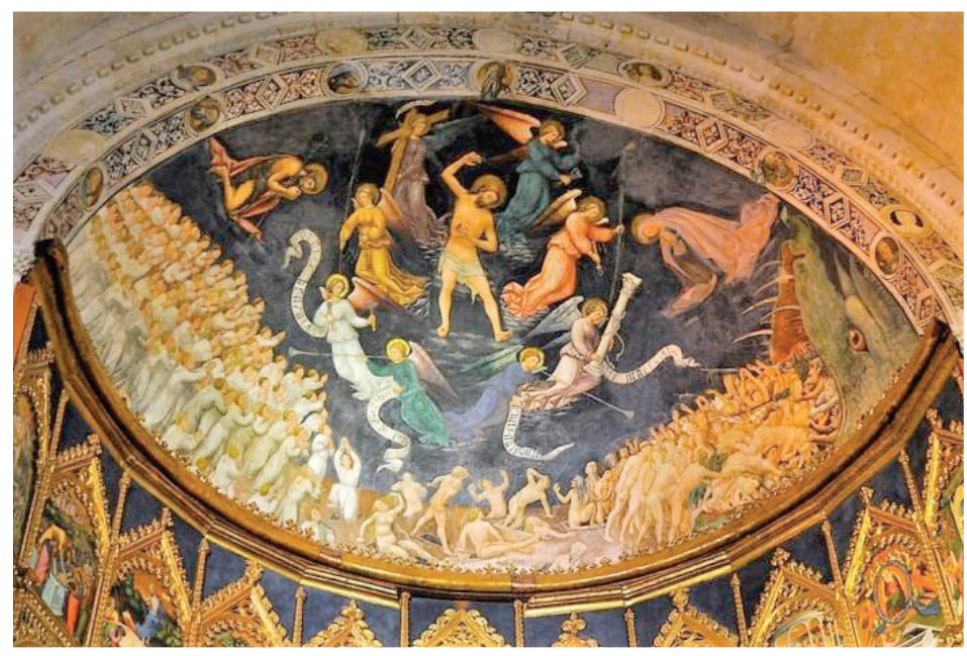

Fig. 20. Nicolás Delli (o Nicolás Florentino), Juicio final, fresco, ca. 1445. Salamanca, Catedral Vieja, bóveda del altar mayor.

56 En un registro superior vuelve a aparecer la gran boca abierta, representación ahora de la Tierra, de la que surgen los muertos desnudos presentando sus libros abiertos. 


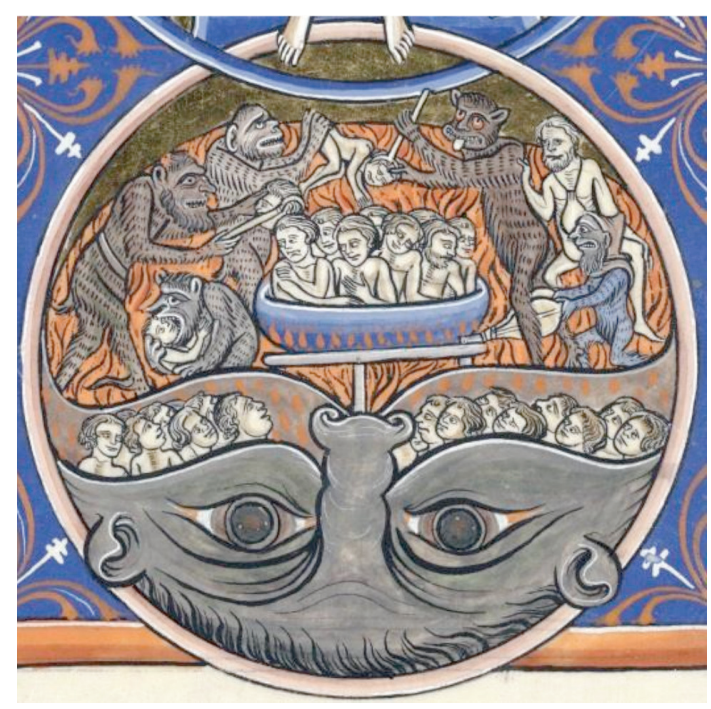

Fig. 21. "Infierno", Salterio de Blanca de Castilla, manuscrito, inicios del s. XIII. París, Bibliothèque de l'Arsenal, ms 1186, f. 171v.

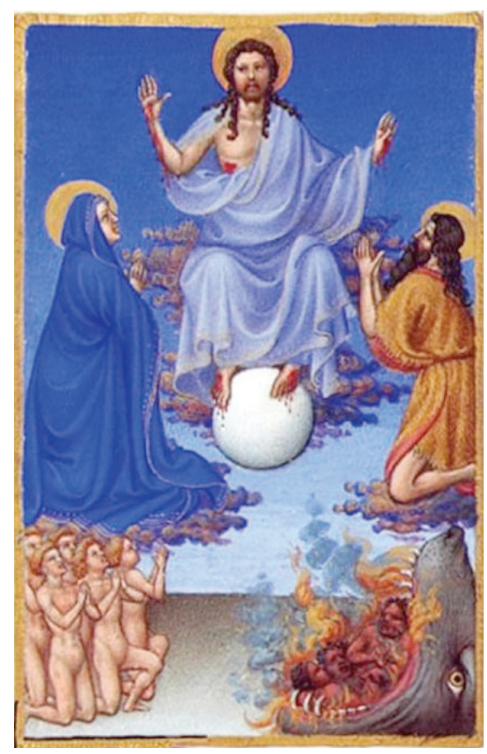

Fig. 22. Paul, Jean y Herman Limbourg, "Cristo Juez", Les très riches heures du duc de Berry, manuscrito, ca. 1416. Chantilly, Musée Condé, ms 65, f. 34r.

Si nos detenemos ahora en un manuscrito del s. XV conservado en la British Library, la Carthusiian Miscellany (Add. ms 37049, fols. 72v-73r), dentro de una representación dibujada a doble página titulada "Salvación y condenación", encontramos a un curioso Leviatán de forma alargada, como si se tratara de un gran gusano con una boca en cada extremo: la de la derecha, en posición vertical, recoge a los de- 
monios expulsados por san Miguel de la fortaleza celeste; la otra boca, en horizontal, espera a los pecadores alineados en doble fila que se dirigen hacia ella. En el ámbito de la pintura tardomedieval, mencionemos el Juicio final de Petrus Christus (Berlín, Staatliche Museen, panel de un retablo desmontado, ca. 1445-1450). En la parte inferior de la tabla, en el reino infernal -aquí delimitado por una singular e imaginativa imagen de la Muerte como esqueleto que hace de escudo para impedir la huida de los condenados-, entre las distintas criaturas maléficas y castigos, son visibles unas grandes fauces abiertas en cuyo interior ardiente pueden distinguirse algunas almas en pena. En un Juicio final anónimo algo posterior (óleo sobre madera trasladado al lienzo, fines del s. XV, París, Musée des Arts Decoratifs), un grupo de condenados gesticulantes se acumula en un gran caldero situado a la entrada de la boca de un temible Leviatán con grandes cuernos y púas de puercoespín sobre la cabeza [Fig. 23].

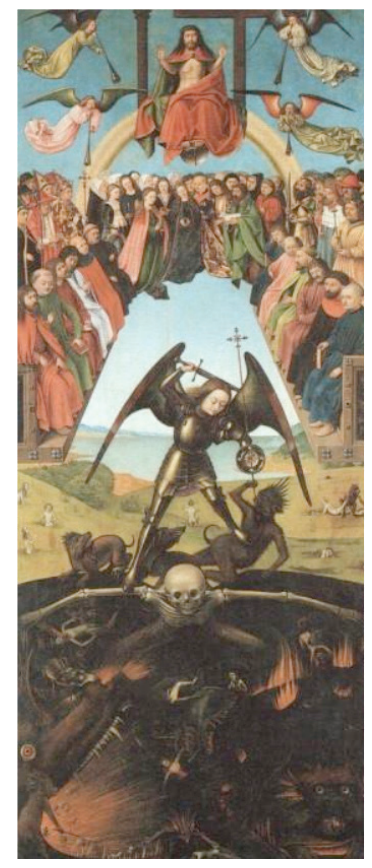

Fig. 23. Petrus Christus, Juicio final, ca. 1445-1450. Berlín, Staatliche Museen.

El tema encontró igualmente un eco considerable en la decoración mural de las iglesias británicas del s. XV, donde proliferan las Bocas del Infierno asociadas a temas apocalípticos, aunque algunas de ellas han sufrido importantes restauraciones en el s. XIX. Un modelo habitual es la representación del Juicio universal adaptada a la forma de los muros de los arcos diafragma de los templos, de modo que Leviatán se localiza siempre en el extremo inferior del lado derecho. Así sucede en la parroquial de St Thomas of Canterbury, en Salisbury (Wiltshire), en las iglesias de St James, en South Leight, y St Lawrence, en Combe, ambas en Oxfordshire, o en la Guild Chapel en Stratford-up-Avon, donde existió un Juicio final hoy perdido, del que nos quedan algunos grabados realizados en el s. XIX. En la parroquial de St Peter en Wenhaston (Suffolk), se conserva un interesante panel pintado semicircular 
de madera, conocido como el Juicio final (The Wenhaston Doom, ca. 1500), que incluye las fauces infernales en una representación muy similar en su composición a los anteriores ejemplos murales [Fig. 24]. También es posible documentar el tipo en la escultura medieval inglesa: así, el ejemplo tallado en madera en el retrocoro de la catedral de Worcester (ca. 1379).

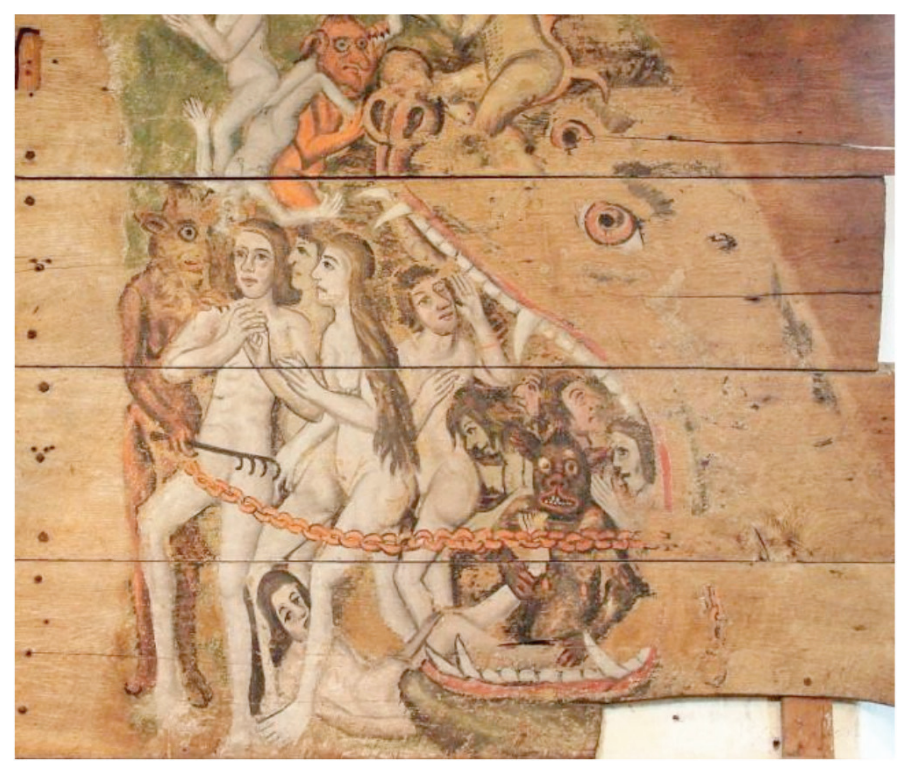

Fig. 24. Juicio final (The Wenhaston Doom), detalle, ca. 1500. Wenhaston (Suffolk, Reino Unido), iglesia de St Peter.

Francia cuenta asimismo con destacados ejemplos murales en torno a estas fechas, en los que la boca de Leviatán se inserta de igual manera en grandes composiciones al fresco de nuestras postrimerías. Muestra remarcable es el "Infierno" que Jean Canavesio realizó para la capilla de Notre-Dame-des-Fontaines, en La Brigue (Francia, 1492), donde la Muerte se sitúa sobre la escena del mismo modo en que lo hace en la ya mencionada tabla de El Juicio final de Petrus Christus.

\subsection{Leviatán como boca monstruosa de entrada al infierno en la Anastasis o Descenso al Limbo}

En cuanto al episodio de la Anastasis ${ }^{57}$ o Descenso de Cristo al Limbo -o al Infierno de los Justos, o al Limbo de los Patriarcas, tema también denominado "Trilla del Infierno" por influjo anglosajón-, de acuerdo con una de sus variantes iconográficas, Jesús ya resucitado, armado con la cruz de la Resurrección, pisotea las puertas del Infierno quebrantadas, que al caer aplastan a Satanás, y planta el extremo de la cruz

57 Término de origen griego que significa literalmente "Resurrección de Cristo", si bien, de forma restringida, se utiliza también para referirse al descenso de Cristo a los Infiernos o Limbo de los Patriarcas, como veremos a continuación. 
en las fauces de Leviatán ${ }^{58}$. Esta monstruosa boca representa la estancia infernal vista a través de los rasgos descritos en el Libro de Job-las llamas y el humo brotan de su cavidad y de sus fosas nasales-. Algunos rasgos iconográficos de este tema proceden muy probablemente, una vez más, de la puesta en escena de los autos sacramentales $^{59}$ : Leviatán aparece como una criatura autónoma, que en las representaciones dramatizadas habla, discute con Satanás, o incluso acusa a éste de haber permitido la irrupción de Cristo; igualmente, la imagen de un demonio aplastado bajo una de las puertas -símbolo de la derrota de los poderes infernales-, o la multiplicación de diablos gesticulantes que contemplan la escena con desesperación, se explica tanto por las "diablerías" teatrales, como por la contaminación de este episodio con el tema del Juicio final. En el Renacimiento se sustituyó a Leviatán por el Hades pagano regido por Plutón y custodiado por el perro tricéfalo Cerbero, que vigila la lúgubre entrada ${ }^{60}$.

Este asunto empezó a difundirse a partir del s. XII, sobre todo en los ámbitos de la iluminación de manuscritos y de la escultura monumental románica. Mencionemos dentro de este último contexto los ejemplos tempranos de una metopa de San Martín de Tours en Artaiz (Navarra, mediados del s. XII), con Cristo liberando a los Justos del Antiguo Testamento de la enorme boca, o el más elaborado y complejo de un capitel del claustro de la catedral de Santa María de Tudela (Navarra, 1186-1203) con el mismo asunto [Fig. 25] ${ }^{61}$. La presencia de la boca infernal en esta escena alcanzará cierta difusión en la escultura gótica a partir de la inclusión del tipo en los retablos de la Pasión en alabastro, fabricados en Inglaterra durante los últimos siglos medievales, y exportados al continente e Islandia. Dos interesantes muestras son las respectivas piezas conservadas en el Museo de Carcassone, en Francia, y en el Victoria and Albert Museum de Londres, ambas del s. XV, con una configuración muy similar. Temática muy frecuente entre los ss. XIV y XV, una representativa obra de estos momentos es el relieve en madera policromada de un anónimo maestro de los Países Bajos del sur o de Colonia, El descenso a los infiernos (Amsterdam, Rijksmuseum, ca. 1460), en el que Cristo, acompañado de dos ángeles, saca con su mano a diversas almas desnudas de entre las llamas de la temible boca. En el retablo mayor procedente de la iglesia conventual del Santo Sepulcro de Zaragoza, hoy en el Museo de Zaragoza, cuyas tablas son obra de Jaime Serra (s. XIV), encontramos también la típica configuración pictórica de este tema: Cristo, situado a la izquierda, ayuda a emerger de la gran boca oscura a los cautivos en el Limbo, que aquí aparecen vestidos con hábitos y túnicas. Los demonios utilizan una gran cadena para tratar de cerrar las fauces [Fig. 26]. Otro ejemplo similar se conserva en la pintura sobre tabla

58 En no pocas ocasiones se combina la boca - que constituye el lugar de salida y entrada para los demonios- con una estructura arquitectónica integrada con más o menos habilidad entre las rocas de la caverna infernal, que puede estar en ruinas tras la irrupción del Salvador, o proporcionar barrera o parapeto desde el que los demonios, impotentes y gesticulantes, observan el "asalto" de Cristo al Infierno.

59 Se conservan algunos bocetos o diseños de época moderna de escenarios teatrales en los que se incorpora una Boca infernal mecánica. El ejemplo más conocido es la ilustración procedente de la obra La Pasión de Valenciennes (París, Bibliothèque nationale de France, ms fr. 12536, fols. 1v-2bis, ca. 1547). En tanto el Paraíso aparece localizado en lo alto de un pabellón a la izquierda, la Boca del Infierno, por la que salen algunos demonios, aparece en la base de una construcción a la derecha. El resto de las arquitecturas representa edificios de Nazaret o Jerusalén, entre otros lugares significativos en la obra.

60 Réau, Louis (2000), Iconografía del arte cristiano, tomo 1, vol. 2: "Iconografía de la Biblia. Nuevo Testamento", Barcelona, Ediciones del Serbal, 555-557.

61 Vid. Aragonés Estella, M ${ }^{\mathrm{a}}$ Esperanza, op. cit., 40-52. 
del Descenso al limbo, en el retablo mayor de la Catedral Vieja de Salamanca, obra de Dello Delli con la colaboración de sus hermanos Sansón y Nicolás (ca. 1434-45); en este conjunto se destaca un Leviatán de color verde, con apariencia entre vegetal y animal -en especial el detalle del ojo-, cuya boca se encontraba clausurada por una puerta de madera, ahora derribada, y una reja como las que cierran la entrada a los castillos, que ya ha sido izada.

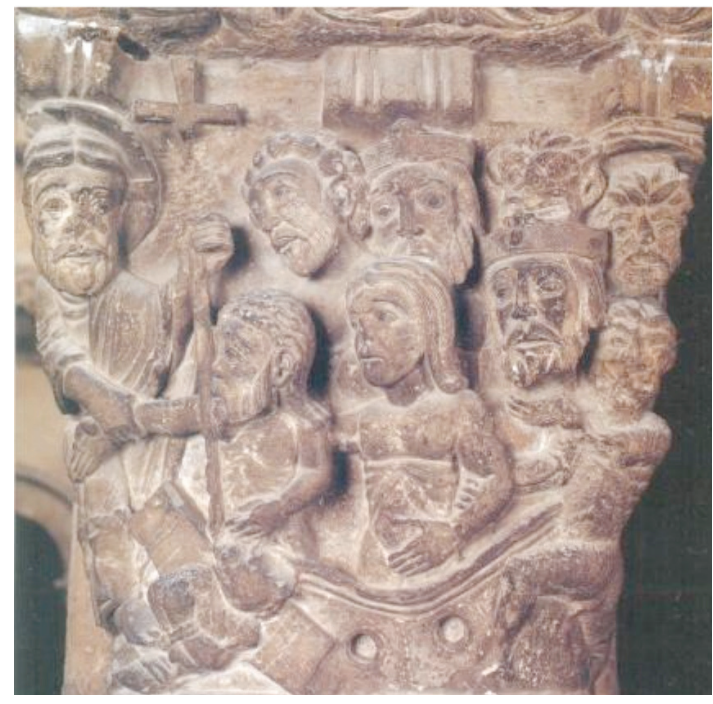

Fig. 25. Cristo liberando a los Justos del Antiguo Testamento de la boca del infierno, 11861203. Tudela (Navarra), catedral de Santa María, capitel del claustro.

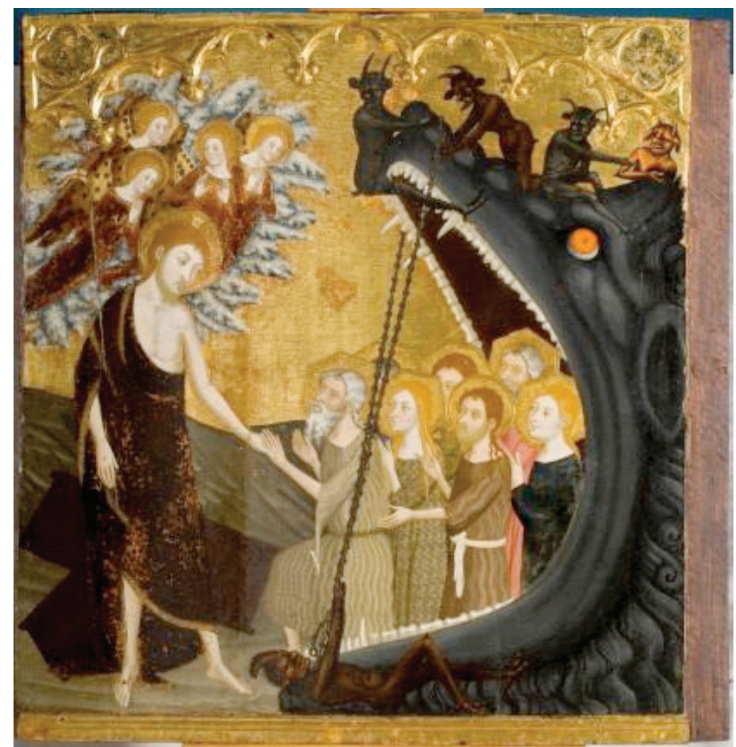

Fig. 26. Jaime Serra, Descenso de Cristo a los Infiernos, s. XIV. Zaragoza, retablo de la Resurrección (procedente de la iglesia del Santo Sepulcro, hoy en el Museo de Zaragoza). 
El tratamiento de este tipo será muy fecundo en la miniatura de los últimos siglos medievales, donde resulta frecuente visualizar al propio Lucifer/Satanás perfectamente distinguible por sus dimensiones y por encontrarse amarrado a merced de Cristo, quien en ocasiones clava su bordón crucífero en la boca del Maligno como elocuente expresión de su victoria. Mencionemos entre los ejemplos del s. XII miniaturas del Salterio de Winchester (Londres, British Library, ms Cotton Nero C. IV, f. 12r, ca. 1150), el Salterio Cotton (Londres, British Library, ms Tiberius C VI, f. 14r, ca. 1050) [Fig. 27], o el Salterio de Saint Albans (Hildesheim, Dombibliothek, ms St Godehard 1, f. 49r, ca. 1120-1145); y, en cuanto a las iluminaciones del s. XIII, ilustraciones procedentes de la Vida de Cristo, manuscrito de origen francés (Nueva York, Pierpont Morgan Library, ms M44, f. 11v, ca. 1175), o de sendos Salterios, el ms Arundel 157 (Londres, British Library, f. 11r, ca. 1240), o el de la Bayerische Staatsbibliothek de Múnich (ms 1.V.13, f. 27, s. XIII), todas ellas composiciones muy similares a las de los ejemplos mencionados de la centuria anterior.

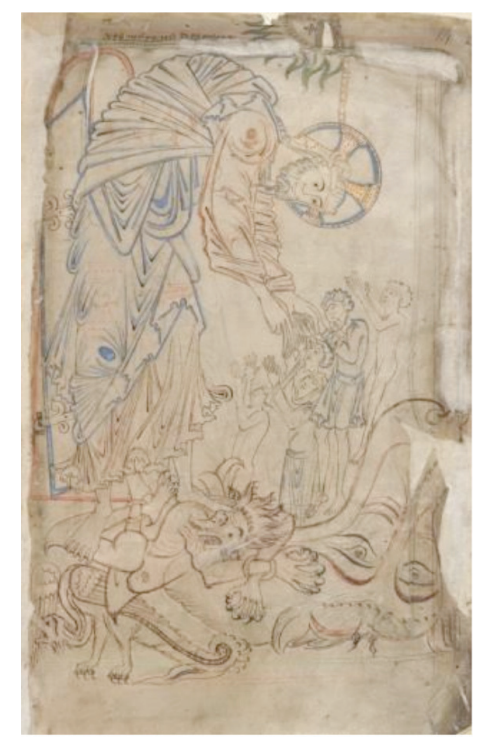

Fig. 27. "Descenso al Limbo",Salterio Cotton, ca.1050. Londres,British Library, ms Tiberius C VI, f. 14r.

El tema resulta muy habitual en la pintura mural bajomedieval danesa, normalmente en las bóvedas de los templos, con resoluciones plásticas por lo general de carácter muy popular e ingenuista. Se pueden encontrar conjuntos datados entre los ss. XIV y XVI en los templos parroquiales de las localidades de Svaerdborg (ca. 1375-1400), Gerlev (ca. 1425, obra de Morton Maler), Over Draaby (ca. 1450, taller Isefjord), Undloese (ca. 1460, taller Union), Hjembaek (ca. 1475) o Estruplund (ca. 1542). En cuanto a la escultura medieval británica, puede mencionarse el detalle decorativo de una ventana de la abadía de Nottinghamshire, en Dorchester (finales del s. XIII).

En el Descenso al Limbo del Holkham Bible Picture Book (Londres, British Library, Add. ms 47682, f. 34r, segundo cuarto del s. XIV), Leviatán no constituye la 
entrada del infierno - que aquí es arquitectónica, desencajada y fragmentada tras la irrupción de Cristo- sino un pintoresco elemento ilustrativo del infierno interior: allí, en vertical, sus fauces calientan una caldera que, a su vez, se encuentra situada dentro de un gran horno por cuya chimenea superior sale el humo [Fig. 28].

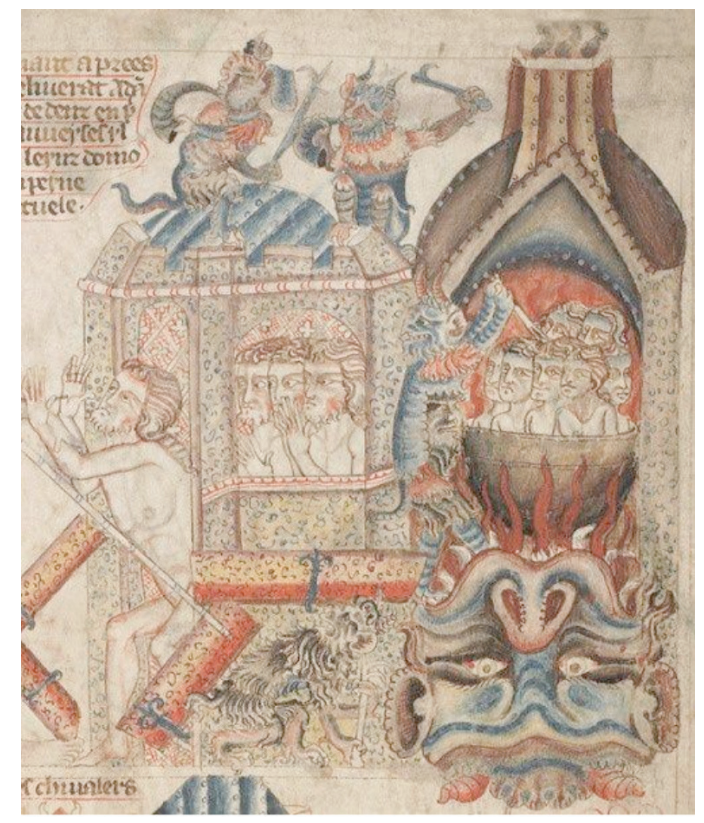

Fig. 28. "Descenso al Limbo", Holkham Bible Picture Book, segundo cuarto del s. XIV. Londres, British Library, Add. ms 47682, f. 34r.

El tipo seguirá estando presente en imágenes grabadas del tránsito del $\mathrm{s}$. XV al XVI: de este modo, lo encontramos en las ilustraciones de la Biblia pauperum en sus sucesivas ediciones, figurando entre las escenas del combate de David y Goliat y la de Sansón luchando con el león.

\subsection{Leviatán como boca monstruosa de entrada al infierno de la que surge la Muerte como jinete del Apocalipsis}

Ya indicamos que el motivo de la boca infernal de Leviatán puede aparecer en otros contextos temáticos más específicos, al margen de los tipos principales enunciados con anterioridad. Uno de los que se reitera con cierta frecuencia en los Apocalipsis iluminados medievales es el de la Muerte como jinete del "caballo pálido" o "lívido" -"verdoso según la Biblia de Jerusalén"-, surgiendo de las fauces de Leviatán tras la apertura del Cuarto Sello, tal y como se describe en $A p$ 6,7-8; en algunas ocasiones, en el interior de la monstruosa boca resultan visibles algunos condenados y demonios, dejando así bien asentada su naturaleza infernal. Ejemplos representativos son las ilustraciones del Apocalipsis de la British Library de Londres (ms Harley 4972, f. 11v), dos Apocalipsis de la biblioteca del Palacio Lambeth, también en Londres (el Lambeth Apocalypse, Londres, Lambeth Palace Library, ms 209, f. 6r, ca. 1260) 
[Fig. 29], uno más francés de finales del s. XIII (Lambeth Palace Library, ms 75, f. $12 \mathrm{v}$ ), éste más elemental en su configuración, otro manuscrito de este texto bíblico realizado en Francia o Inglaterra (París, Bibliothèque nationale de France, ms fr. 403, f. 9, ca. 1240-50), o el Apocalipsis Cloister (Nueva York, Metropolitan Museum of Art, Cloisters Collection 1968, ms 68.174, f. 9r, inicios del s. XIV), composición esta última claramente inspirada en la ilustración mencionada del Lambeth Apocalypse, y donde la boca, repleta de réprobos, presenta igualmente hasta tres rostros monstruosos. En un Apocalipsis flamenco iluminado (París, Bibliothèque nationale de France, ms néerl. 3, ca. 1400), encontramos nuevamente en su lámina 6 a la Muerte a caballo surgiendo de una boca ardiente en la que resultan visibles algunos demonios rojos y una serpiente; del mismo modo, las terribles fauces se emplearán para representar, en la lámina 9 del mismo manuscrito, el abismo o pozo humeante del que surgen las langostas monstruosas descritas en $A p$ 9,2-3.

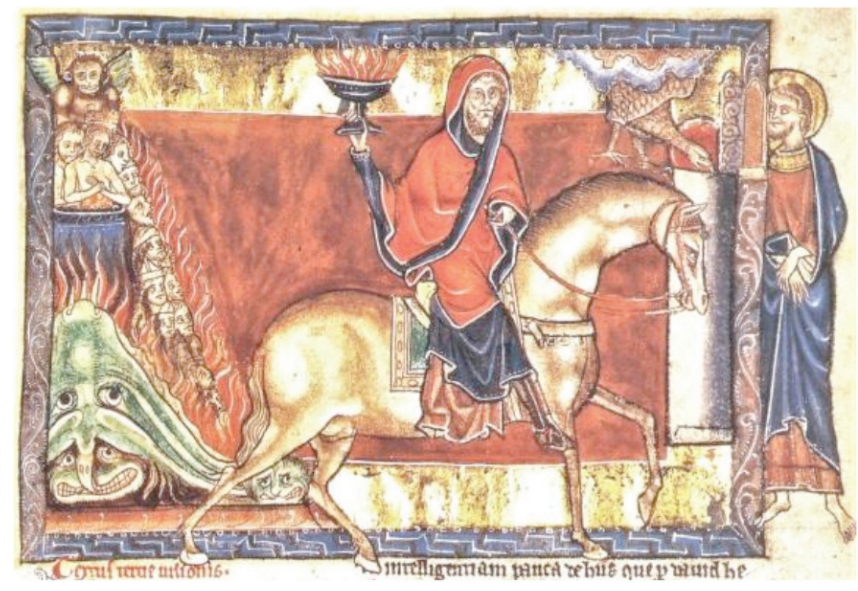

Fig. 29. "El caballero sobre el caballo lívido surgiendo de la boca del infierno", Lambeth Apocalypse, ca. 1260. Londres, Lambeth Palace Library, ms 209, f. 6r.

El tipo se perpetuará en las imágenes grabadas de los Cuatro jinetes del Apocalipsis que proliferaron durante el Renacimiento nórdico, comenzando por la impresionante que Alberto Durero realizó para su Apocalipsis (Nuremberg, 1498), seguramente inspirada en ilustraciones bíblicas inmediatamente anteriores ${ }^{62}$, y continuando con los imitadores de ésta.

Jurgis Baltrusaitis ${ }^{63}$ ha puesto de manifiesto la existencia de una curiosa variante del tipo anterior, en la que las fauces ardientes de Leviatán, en las representaciones de la Apertura del Cuarto Sello, probablemente de acuerdo con el ya citado pasaje: "Miré entonces y había un caballo verdoso; el que lo montaba se llamaba Muerte, y el Hades le seguía" (Ap 6,8), se muestran como un ente autónomo, con dos patas, que parece perseguir a la Muerte sobre el caballo pálido. Este autor aporta los ejemplos procedentes de diversos Apocalipsis anglonormandos: el ms Douce 180 de Oxford

62 Nos referimos a una ilustración xilográfica de la Biblia alemana conocida como Biblia de Schönsperger (Augsburgo, 1490), vol. II, f. 497v.

63 (1987) La Edad Media fantástica. Antigüedades y exotismos en el arte gótico, Madrid, Cátedra, 13-15. 
(1270), el ms 815, f. 9v, de la biblioteca de Toulouse -procedente del convento de Agustinos de la misma ciudad- (ca. 1286-1314), o el ms A 177 de la Landesbibliothek de Dresde, f. 23 (s. XIV) ${ }^{64}$, al que nosotros incorporamos una ilustración del Apocalipsis de Alexander Minorita, redacción final (1249-50) del comentario al Apocalipsis del franciscano Alexander de Bremen (Cambridge, Cambridge University Library, ms 5.31, f. 27v) [Fig. 30].

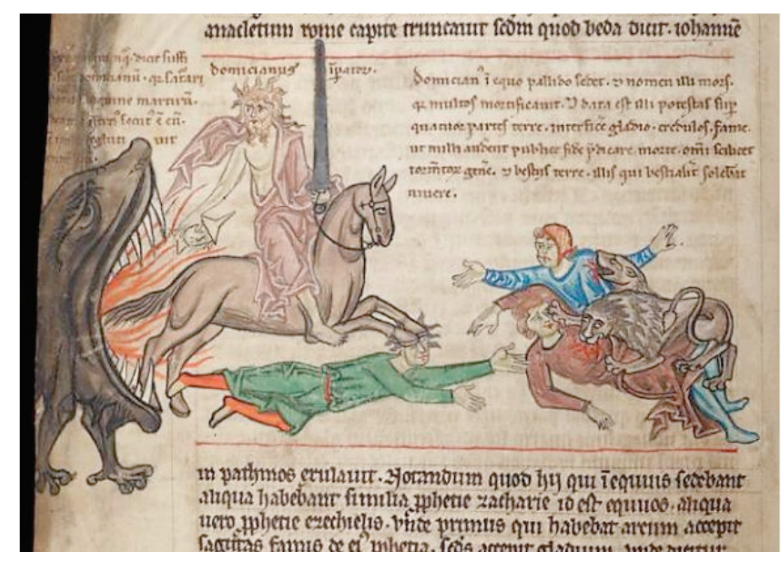

Fig. 30. "El caballero sobre el caballo lívido surgiendo de la boca del infierno" o "Apertura del cuarto sello", Apocalipsis de Alexander Minorita, manuscrito, ca. 1249-50. Cambridge, Cambridge University Library, ms 5.31, f. 27v.

\subsection{El infierno en el que caen los ángeles rebeldes representado como la boca de Leviatán}

El asunto iconográfico de la rebeldía y expulsión del cielo de los ángeles que, al principio de los tiempos -en el momento de la Creación según la tradición patrística más asentada-, se apartaron de la voluntad de Dios y se enfrentaron a ella, cuenta con sus primeras concreciones gráficas en el s. XI. En una iluminación anglosajona de un Hexateúco (Londres, British Library, Cotton Claudius ms B IV, f. 2r), fechable entre el segundo cuarto de aquella centuria y la segunda mitad del XII, se muestra a Dios en una mandorla junto a sus ángeles expulsando a los rebeldes, que, desprovistos ya de alas y tan sólo ataviados con una falda rústica, todavía presentan una fisonomía humanizada próxima a la de aquéllos con los que combaten. Satanás está dentro de otra mandorla -remedo de la divina- situada entre las fauces de un gran dragón-Leviatán, detalle que, a partir de este momento, resultará muy habitual como efectista recurso para representar su precipitación en el Averno de los reiecti [Fig. 31]. Otra ilustración italiana, ya en el s. XIV, del Tratado sobre los Siete Vicios (Londres, British Library, Add. ms 27659, f. 1v) nos presenta a unos ángeles rebeldes alados similares a los de Tréveris, precipitándose ahora dentro de las mandíbulas de la temible Boca del Infierno.

64 El propio Baltrusaitis - op. cit., 15- añade igualmente un ejemplo dentro del tema del Descenso al limbo, procedente de un manuscrito de la biblioteca August Herzog de Wolfenbüttel, Alemania (después de 1235), en el que las grandes fauces de las que Cristo está redimiendo a diversas almas presentan, de igual modo, sendas patas. 


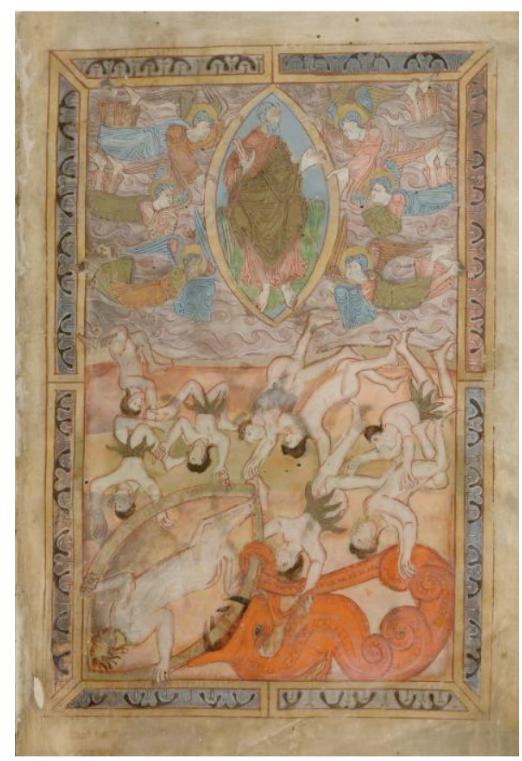

Fig. 31. "La caída de los ángeles rebeldes", Hexateúco, manuscrito, $2^{\circ}$ cuarto s. XI-2 a mitad s. XII. Londres, British Library, Cotton Claudius ms B IV, f. 2r.

Conforme avanza este periodo, los ángeles derrocados irán intensificando la morfología monstruosa y grotesca que ya resultará habitual en el imaginario de los seres demoníacos hasta inicios de los tiempos modernos. Una ilustración del Salterio de Blanca de Castilla y San Luis (París, Bibliothèque de l'Arsenal, ms 1186, f. $9 \mathrm{v}$, ca. 1230) muestra a Cristo entronizado, rodeado de los ángeles leales que le rinden pleitesía, en actitud de bendecir en el interior de una mandorla trilobulada; por debajo de ella vemos a los ángeles caídos en dos fases diferentes de su descenso a los infiernos: en una banda superior, situada bajo la mandorla, se precipitan boca abajo, todavía con todos sus rasgos angélicos, pero con evidentes gestos de angustia y arrepentimiento en el rostro. En una banda inferior, ahora rodeados de las llamas infernales, los vemos ya transformados en seres peludos que conservan las alas, pero cuyos cuerpos y cabezas han adquirido grotescos añadidos zoomórficos, al tiempo que penetran en una enorme boca infernal dotada de temibles rasgos faciales [Fig. 32].

Otros dos ejemplos, ambos realizados por el miniaturista William de Brailes, los localizamos, en un primer caso, en una Biblia inglesa de mediados del s. XIII (Baltimore, Maryland, EE. UU., Walters Art Museum, ms w. 106, f. 24r), donde un Lucifer aún humanizado se mezcla con demonios de color pardo oscuro en su entrada en la enorme boca zoomorfa - resulta aquí muy interesante la rígida estructura en círculos concéntricos del cielo, articulada en torno a Cristo bendiciendo en una posición central- [Fig. 33]; la segunda composición se incluye en un Salterio de la misma cronología (Cambridge, Fitzwilliam Museum, ms 330.iii, f. 1, ca. 1240), conforme a un esquema general similar, pero donde los demonios que caen, mucho más diversificados en sus formas y colores, son recibidos en las fauces de Leviatán por sendos congéneres provistos de largos palos. 


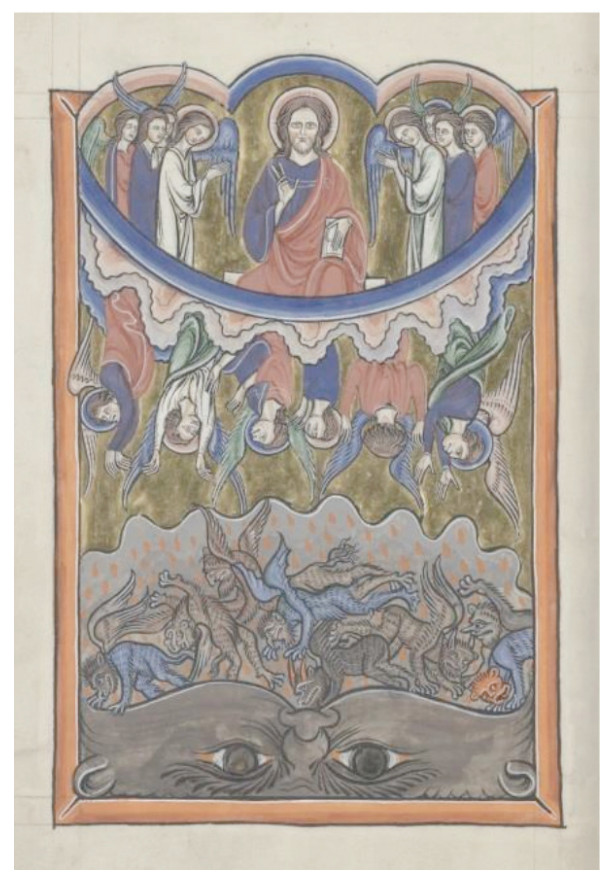

Fig. 32. "La caída de los ángeles rebeldes", Salterio de Blanca de Castilla manuscrito, antes de 1223. París, Bibliothèque de l'Arsenal, ms 1.186, f. 9v.

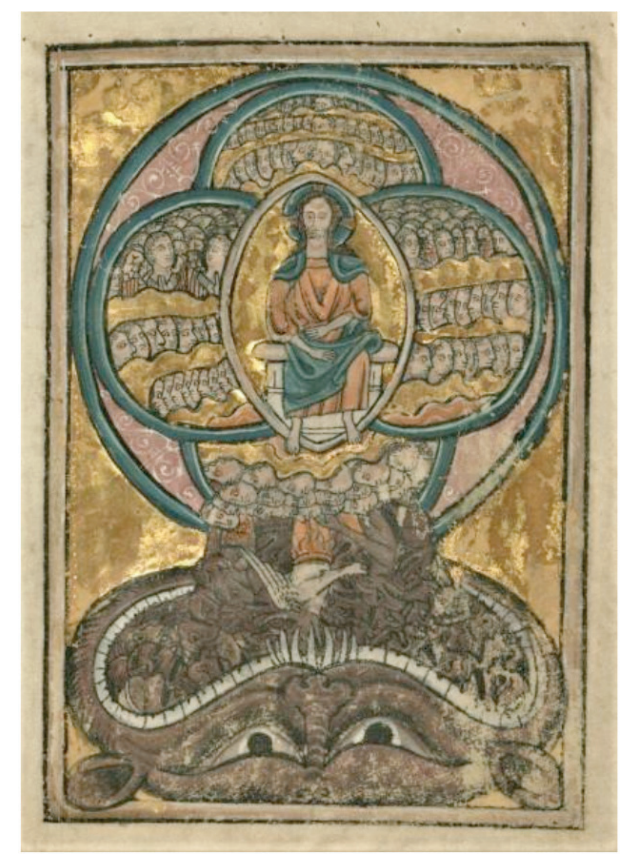

Fig. 33. William de Brailes, "La caída de los ángeles rebeldes", Biblia inglesa, mediados del s. XIII. Baltimore (Maryland, EE. UU.), Walters Art Museum, ms w. 106, f. 24r. 
Variante interesante dentro de esta serie es la que nos ofrece una ilustración del Breviari d'Amor, manuscrito francés iluminado del último cuarto del s. XIV escrito por Matfré Ermengaud de Béziers (British Library, ms Yates Thompson 31). Formando parte de una iluminación a página completa -f. 43- en la que se describen distintas actividades de los demonios, se incluye en su parte superior la caída de los ángeles rebeldes, ya sometidos a diversas hibridaciones, en la boca de Leviatán concebida como enormes fauces de doble rostro de las que surgen llamas. El cielo sobre ellos es un espacio azul densamente estrellado. Cristo entronizado no aparece pasivo en esta ocasión, y, de manera sorprendente, parece ayudar a los ángeles fieles en su combate sirviéndose de una larga vara o pértiga, y dando instrucciones a sus legiones [Fig. 34] ${ }^{65}$. También en la Biblia historiada de Guiard des Moulins (Bruselas, Bibliothèque Royale, ms 9001, f. 19), de principios del s. XV, los ángeles caídos, que exteriorizan su congoja e inclinan la cabeza agónicamente, se transforman en criaturas dotadas de alas de murciélago y garras.

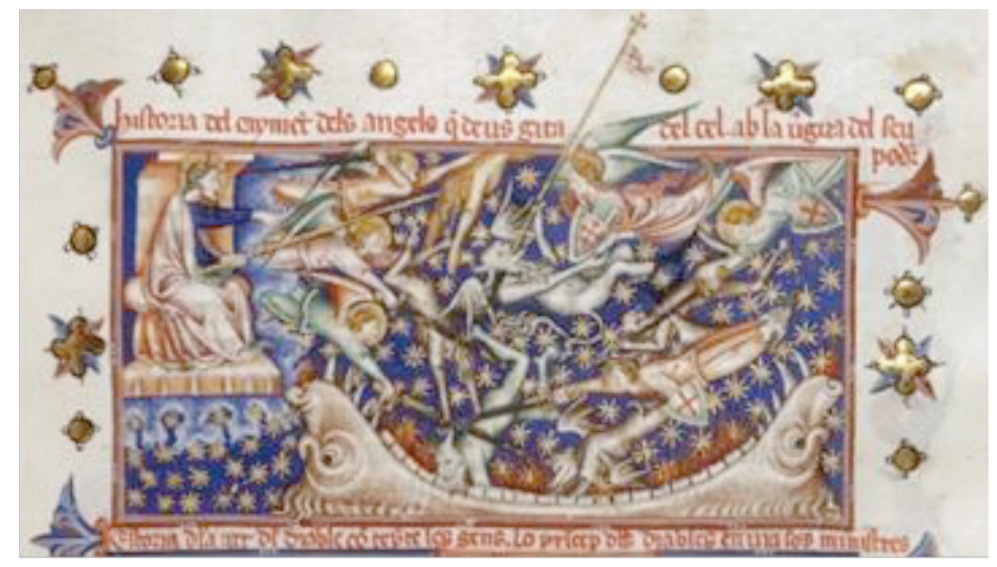

Fig. 34. "La caída de los ángeles rebeldes", Breviari d'Amor de Matfré Ermengaud de Béziers, manuscrito, último cuarto del s. XIV. Londres, British Library, ms Yates Thompson 31, f. 43.

Un elaborado y completo exponente de la proliferación de este asunto en los momentos finales de la Edad Media, con la correspondiente inclusión de la Boca del Infierno, se localiza en un manuscrito procedente de Tours (Francia) del Livre des anges de Francisco de Ximénez (Londres, British Library, ms Sloane 3049, f. 71 , ca. 1480), en una escena ahora presidida por Dios Padre con tiara y orbe en su mano izquierda, y donde los demonios expulsados presentan rasgos esencialmente antropomorfos [Fig. 35]. Pero es también posible encontrar, por estas mismas fechas, muestras más sencillas o sintéticas del mismo episodio, en las que se prescinde de la corte celeste. Es el caso de un Salterio-Libro de Horas procedente de Amiens, Francia (Nueva York, The Morgan Library \& Museum, ms M.729, f. 404v, ca. 128099), o una Bible moralisée procedente de Brujas, Bélgica (La Haya, Koninklijke Bibliotheek, ms KB, 76 E 7, f. 1, ca. 1455-1460), donde el combate celeste se limita,

65 Ward, Laura y Steeds, Will (2007), Demonios. Visión del Diablo en el arte, Madrid, Edilupa, 31. 
respectivamente, a tres y dos ángeles que alancean a unos feroces demonios de alas membranosas en plena caída; en otro manuscrito francés del ya mencionado Breviari d'Amor de Ermengaud de Béziers (Londres, British Library, ms Royal 19 C I, f. 33, primer cuarto del s. XIV), la representación de los combativos ángeles fieles se ve drásticamente reducida a una mano, identificada como la de Cristo por el nimbo crucífero sobre el que se superpone, que sujeta una larga vara con la que parece fustigar a sus adversarios ${ }^{66}$.

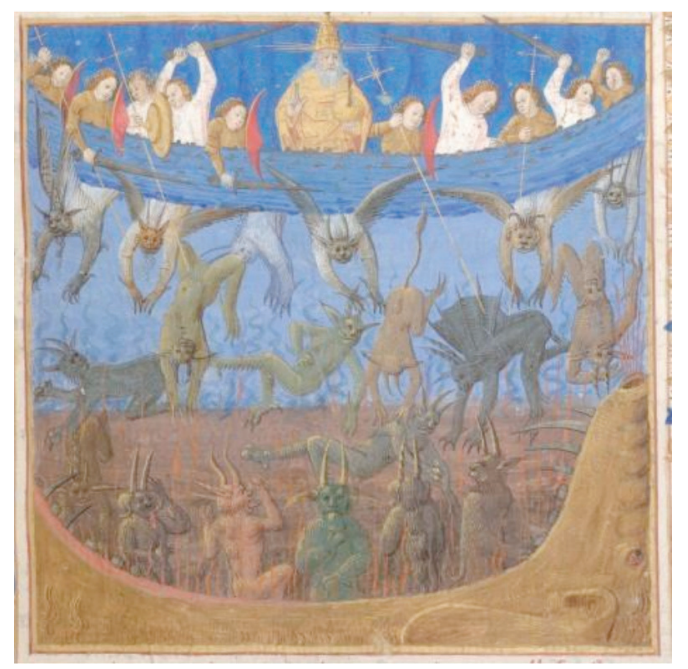

Fig. 35. "La caída de los ángeles rebeldes", Livre des anges de Francisco de Ximénez, manuscrito, ca. 1480. Londres, British Library, ms Sloane 3049, f. 71.

Este tipo pasa muy pronto al ámbito del grabado, conservando inicialmente la estructura compositiva de las miniaturas medievales. Encontramos, por ejemplo, el Casus Luciferi ["La Caída de Lucifer"] en una de las xilografías de la Biblia pauperum (Bamberg, 1470). De nuevo Cristo, dispuesto sobre unas nubes, contempla cómo sus ángeles armados con espadas y lanzas derriban a unos demonios ya metamorfoseados, con rasgos bestiales y alas membranosas, que se precipitan sobre unas enormes fauces llameantes ${ }^{67}$.

\subsection{Leviatán como boca monstruosa de entrada al infierno situada el centro de un esquema cosmográfico}

A modo de apartado final, no queremos dejar de mencionar algunas ilustraciones en las que las grandes fauces zoomórficas, conteniendo en su interior a un grupo de condenados, pueden aparecer en el centro de ciertos esquemas cosmográficos, formados por círculos concéntricos, que definen los distintos niveles y órbitas de los planetas

\footnotetext{
66 Recordemos, como acabamos de indicar más arriba, que en otros ejemplares ilustrados de la misma obra Cristo aparece sedente, sirviéndose de este mismo instrumento para ayudar o impartir instrucciones a sus ángeles fieles.

${ }^{67}$ Vid. Lehner, Ernst y Lehner, Johanna (1971), op. cit., 25, fig. 50.
} 
entre el cielo y el infierno, conformando una imagen minimizada del infierno en el núcleo de la tierra. Un esquema sencillo puede contemplarse en un manuscrito del s. XIII de la Image du monde de Gossuin de Metz (París, Bibliothèque nationale de France, ms fr. 14970, f. 48r, ca. 1285), o situado en el centro de las esferas celestes, conformando de nuevo una estructura circular concéntrica que ahora incluye una representación de la Maiestas Domini en lo alto, en otra versión coetánea de la misma obra (Paris, Bibliothèque nationale de France, ms fr. 14964, f. 117r) [Fig. 36]. Este último tipo se mantiene hasta fines de la Edad Media, como puede contemplarse en otra ilustración de la versión de la misma obra de 1464 conservada en la British Library (ms Royal 19

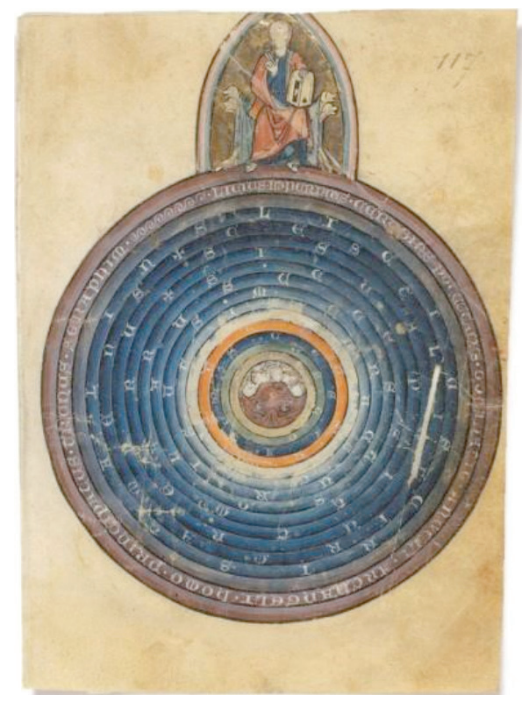

Fig. 36. Infierno como boca de Leviatán en el centro de las esferas celestes, manuscrito, fines del s. XIII. París, Bibliothèque nationale de France, ms fr. 14964, f. 117r.A IX, f. 149r).

\section{Conclusión}

De todo lo visto en las páginas precedentes puede concluirse, en primer lugar, que la más temprana tradición judeo-cristiana, fundamentándose en los diversos pasajes bíblicos que aluden a la mítica y colosal criatura acuática derrotada por el poder divino que llegará a ser conocida bajo el nombre de Leviatán, recoge los rasgos y denominación de aquélla para transformarla, ya en manos de los Padres de la Iglesia, en una de las más llamativas formas o encarnaciones del Diablo en la cultura occidental. Por otra parte, de entre las diversas apariencias o tipos iconográficos que esta entidad adquirirá en el imaginario europeo, su caracterización como monstruosa y llameante boca zoomorfa del infierno será la que obtenga un éxito más rotundo y duradero durante los últimos siglos medievales, llegando a erigirse en componente casi obligado en cualquier representación en la que la entrada al inframundo constituya una parte de su imaginario. Adquiere para ello los rasgos de diversos animales 
antropófagos o "devorantes", ya sean reales, como el lobo, el oso, el león o un gran cetáceo, ya sean fabulosos, como el dragón, llegando a asumir incluso un aspecto antropomorfo más o menos grotesco conforme avanzamos ya en el quinientos. Así, a lo largo de los ejemplos mencionados, lo hemos visto como parte integrante de diversos contextos pre- o ante-infernales, o incluso como elemento constituyente de las visiones del averno, y aún seguirá manteniendo una cierta vigencia durante los $\mathrm{s}$. XVI y XVII, aunque en esta última centuria será ya un icono restringido a composiciones de carácter bastante retardatario.

Tal reactivación moderna resultó especialmente llamativa en ciertos contextos icónicos de orientación crítica o satírica como es, por ejemplo, el ámbito de la estampa propagandística

protestante o anti-católica, en la que se convierte en alegorización del tremendo y eterno castigo

que aguarda al clero corrupto y a cuantos se alían con él. A tan amplia y prolongada difusión contribuirá sin duda el frecuente recurso en los autos sacramentales o el teatro popular a ingenios escénicos móviles con aspecto de grandes cabezas zoomorfas llameantes o humeantes, cuya incidencia o interacción con las artes plásticas es para algunos investigadores incuestionable en determinados ámbitos europeos a la vista de los elementos arquitectónicos o cadenas de arrastre que son incorporados a algunas de las representaciones. Sin duda la evidente capacidad de esta figura para atemorizar a los fieles, a la que podríamos calificar de feliz hallazgo como plasmación ilustrativa y efectiva de las indescriptibles e inimaginables penas que aguardan en su interior, contribuyó al éxito duradero de esta configuración y a su profundo arraigo en el imaginario popular.

\section{Referencias bibliográficas}

Aragonés Estella, Ma Esperanza, 1996, La imagen del mal en el románico navarro, Pamplona, Gobierno de Navarra.

Baltrusaitis, Jurgis, 1987, La Edad Media fantástica. Antigüedades y exotismos en el arte gótico, Madrid, Cátedra.

Barber, Richard y Riches, Anne, 1975, A Dictionary of Fabulous Beasts, Ipswich, The Boydell Press.

Biblia de Jerusalén (1994), Bilbao, Desclée de Brower / Alianza Editorial.

Blanc, Monique, 2004, Voyages en enfer. De l'art paléochrétien à nos jours, Paris, Citadelles $\&$ Mazenod.

Bousquet, Louis J., 1948, Le jugement dernier au tympan de l'église de Sainte-Foy de Conques, Rodez, Imp. P. Carrere.

Brandon, Samuel George F., 1975, Diccionario de religiones comparadas, Madrid, Ediciones Cristiandad (2 vols.).

Castel Ronda, Elisa, 1995, Diccionario de mitología egipcia, Madrid, Alderabán.

Champeaux, Gerard de y Sébastien Sterckx, Dom Sébastien (1985), Introducción a los símbolos, Madrid, Ediciones Encuentro.

Chevalier, Jean y Gheerbrant, Alain, 1988, Diccionario de símbolos, Barcelona, Herder.

Cohn, Norman, 1995, El cosmos, el caos y el mundo venidero. Las antiguas raíces de la fe apocalíptica, Barcelona, Crítica.

De Santos Otero, Aurelio (ed. y trad.), 1988, Los Evangelios Apócrifos, Madrid,BAC. 
Didron, Adolphe Napoléon, 1965, Christian Iconography. The History of Christian Art in the Middle Ages, Nueva York, Frederick Ungar Publishing (2 vols.).

Drewer, Lois, 1981, "Leviathán, Behemot and Ziz. A Christian Adaptation”, Journal of the Warburg and Courtauld Institutes 44, 148-156.

Galpern, Joyce Ruth M., 1977, The Shape of Hell in Anglo-Saxon England, tesis doctoral inédita, Berkeley, Universidad de California.

Gibson, John C. L., 1978, Canaanite Myths and Legends, Edimburgo, T. \& T. Clarke, 1978. Graves, Robert y Patai, Raphael (2009), Los mitos hebreos, Madrid, Alianza.

Gregorio Magno, 1998, Libros morales/1 (I-V), traducción de Rico Pavés, J., Madrid, Ciudad Nueva. Grimal, Pierre, 1989, Diccionario de mitología griega y romana, Paidós, Barcelona, Paidós.

Guttman, Alexander, 1968, "Leviathan, Behemoth and Ziz: Jewish Messianic Symbols in Art", Hebrew Union College Annual 39, 219-230.

Interián de Ayala, Juan, 1883, El pintor cristiano y erudito, Barcelona, Imprenta de la Viuda e Hijos de J. Subirana.

Isidoro de Sevilla, 1982, Etimologías, texto latino, versión española y notas de J. Oroz Reta y M. A. Marcos Casquero, Madrid, BAC (2 vols.).

Le Goff, Jacques, 1989, El nacimiento del Purgatorio, Madrid, Taurus.

Lehner, Ernst y Lehner, Johanna, 1971, Picture Book of Devils, Demons and Witchcraft, Nueva York, Dover.

Libro de Enoc el Profeta (El), 2005, traducción española de Navascués, Fermín, a partir de la versión inglesa del texto etíope realizada por Charles, R. H., Madrid, Edaf.

Link, Luther, 2002, El diablo. Una máscara sin rostro, Madrid, Síntesis.

Lima, Robert, 1996, "The Mouth of Hell: the Iconography of Damnation On the Stage of the Middle Ages, en Szonyi, Gyorgy E. (ed.), European Iconography East and West, Selected Papers of the Szeged International Conference, June 9-12, 1993, Leiden, Brill, 35-48.

Lurker, Manfred, 1994, Diccionario de imágenes y símbolos de la Biblia, Madrid, El Almendro. Luis de León, 1985, Exposición del Libro de Job, Madrid, Hyspamérica Ediciones.

Meredith, Peter, 1992, "The Iconography of Hell in the English Cycles: A Practical Perspective", en Davidson, Clifford y Seiler, Thomas H. (eds.), The Iconography of Hell, Kalamazoo, MI, Medieval Institute Publications, 175-176.

Michaëlis, Sebastien, 1612, Histoire admirable de la possession d'une penitente, París, Charles Chastellain.

Migne, Jean-Paul (ed.), 1844-1855, Patrologia Latina, Paris (222 vols.).

Poesch, Jessie, 1970, "The Beasts from Job in the Liber Floridus Manuscripts", Journal of the Warburg and Courtauld Institutes 33, 41-51.

Réau, Louis, 2000, Iconografía del arte cristiano, tomo 1, vol. 2: "Iconografía de la Biblia. Nuevo Testamento", Barcelona, Ediciones del Serbal.

Russell, Jeffrey Burton, 1994, El Príncipe de las Tinieblas. El poder del mal y del bien en la historia, Santiago de Chile, Andrés Bello.

Schapiro, Meyer, 1980, "Cain's Jaw-Bone that Did the First Murder", en Selected Papers, vol. 3: "Late Antique, Early Christian and Mediaeval Art", London, Chatto \& Windus, 257-259.

Schmidt, Gary D., 1995, The Iconography of the Mouth of Hell: Eighth-Century Britain to the Fifteenth Century, Selinsgrove, PA, Susquehanna University Press.

Schmitt, Carl, 1938, Der Leviathan in der Staatslehre des Thomas Hobbes. Sinn und Fehlschlag eines politischen Symbols, Hamburgo, Hanseatische Verlagsanstalt. 
Sheingorn, Pamela, 1992, “'Who can Open the Doors of his Face?' The Iconography of Hell Mouth", en Davidson, C. y Seiler, Th. H. (eds.), The Iconography of Hell, Kalamazoo (Michigan), Medieval Institute Publications, 1-19.

Turner, Alice K., 1995, History of Hell, San Diego/Nueva York/Londres, A Harvest Book. Ward, Laura y Steeds, Will, 2007, Demonios. Visión del Diablo en el arte, Madrid, Edilupa.

Zamora Calvo, Ma Jesús, 2008, "Las bocas del Diablo. Tratados demonológicos en los siglos XVI y XVII", Edad de Oro 27, 411-445. 